\title{
Stromatolites of the
}

Belt Series in

Glacier National Park

and Vicinity, Montana

By RICHARD REZAK

SHORTER CONTRIBUTIONS TO GENERAL GEOLOGY

GEOLOGICAL SURVEY PROFESSIONAL PAPER 294-D

Descriptions of eight zones of

Precambrian stromatolites, including

two new forms, based on a revised

method of classification

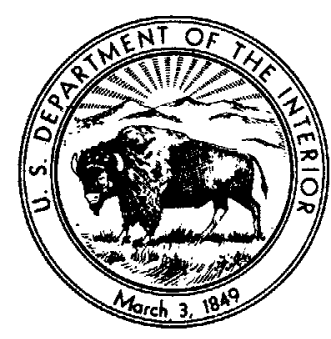

UNITED STATES GOVERNMENT PRINTING OFFICE, WASHINGTON : 1957 


\section{UNITED STATES DEPARTMENT OF THE INTERIOR \\ FRED A. SEATON, Secretary \\ GEOLOGIGAL SURVEY \\ Thomas B. Nolan, Director}

For sale by the Superintendent of Documents, U. S. Government Printing Office Washington 25, D. C. 


\section{CONTENTS}

Abstract

Introduction . . . . . . . . .

Previous investigations. . . . . . .

Present investigation.

Area of investigation. . .

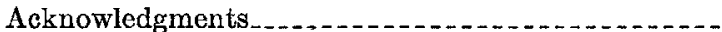

Classification of stromatolites .

General

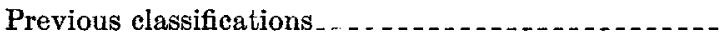

Present classification

Generic distinction

Specific characteristics

Gross form of colony

Nature of the laminae.

Size of colony . . .

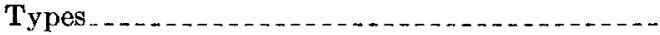

Key to the identification of stromatolites in the Belt series

Descriptions of genera and species....

Genus Cryptozoon Hall...............................

Genus Collenia Walcott

Genus Newlandia Walcott........................

Genus Conophyton Maslov........

Stratigraphy

General

Stromatolite zones . .

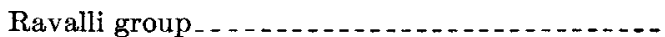

Altyn limestone. . . . . . . . . . . . . .

Collenia frequens zone.

Page
127
127
127
127
128
129
129
129
130
131
131
131
131
132
132
132
132
132
132
133
134
135
135
135
136
136
136
136

Page

127

127

127
127

128

129

129

129

131

131

131

131

132

132

132

132

132

133

134

135

135

136

136

136
Stratigraphy-Continued

Stromatolite zones-Continued

Ravalli group-Continued Page

Grinnell argillite.................. 136

Collenia undosa zone 1............. 136

Piegan group........ 137

Siyeh limestone........... 137

Collenia symmetrica zone 1_....... 137

Conophyton zone 1_................ 138

Collenia multiflabella zone.......... 138

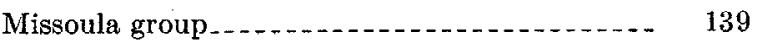

Collenia undosa zone 2 ................ 139

Collenia symmetrica zone 2 _.......... 139

Conophyton zone 2.................. 140

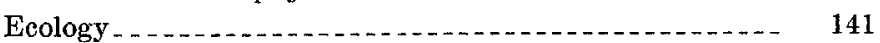

Modern environments _................ 141

Origin of stromatolites....................... 146

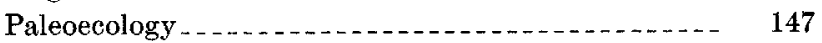

Collenia frequens zone...................... 147

Newlandia lamellosa._._.................. 147

Collenia undosa zones._._............... 147

Collenia symmetrica zones................ 148

Conophyton zones........................... 148

Collenia multiflabella zone................... 148

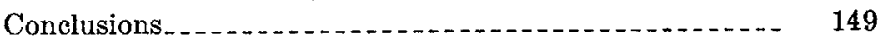

Selected bibliography _................... 149

Index. . . . . . 153

\section{ILLUSTRATIONS}

[Plates 19-24 follow page 154]

Plate 18. Outcrop of Conophyton zone 1 in McDonald valley

19. Illustrations to accompany key to the identification of stromatolites.

20. Collenia frequens Walcott and Cryptozoon occidentale Dawson.

21. Cryptozoon occidentale Dawson, Collenia undosa Walcott, and Collenia mulliflabella n. sp.

22. Collenia multiflabella n. sp., lithoid tufa, and Collenia symmetrica Fenton and Fenton.

23. Conophyton inclinatum $\mathrm{n}$. sp., dendritic tufa, and Newlandia lamellosa Walcott.

24. Recent algal deposits and photomicrographs of Collenia and lithoid tufa.

25. Stromatolite localities in Glacier National Park. In pocket

FIGURE 49. Map of northwestern Montana and adjacent States, showing area of investigation and localities mentioned in text

50. Stromatolite zones in Glacier National Park

51. Algal deposits of type $A$ (after Black, 1933)

deposits of type $A$ (after Black, 1933) $\ldots \ldots \ldots \ldots$

52. Algal deposits of type $B$ (after Black, 1933)

53. Algal deposits of type $C$ (after Black, 1933)

54. Sequence of growth of algal deposits of type $C$ (after Black, 1933)

55. Algal deposits of type $D$ (after Black, 1933)

144 


\title{
STROMATOLITES OF THE BELT SERIES IN GLAGIER NATIONAL PARK AND VICINITY, MONTANA
}

\author{
By Richard REZAK
}

\begin{abstract} for local correlation are recognized in the Belt series of the Glacier National Park region, Montana. The zones vary in composition, thickness, and areal extent. Some are wideonly in small areas. Their names are taken from the dominant species that occurs in each zone. The zones are, from youngest to oldest-

$\left.\begin{array}{l}\text { Conophyton zone } 2 \\ \text { Collenia symmetrica zone } 2 \\ \text { Collenia undosa zone } 2 \\ \text { Collenia multiflabella zone } \\ \text { Conophyton zone } 1 \\ \text { Collenia symmetrica zone } 1 \\ \begin{array}{l}\text { Collenia undosa zone } 1 \\ \text { Collenia frequens zone }\end{array}\end{array}\right\}$ Missoula group
Piegan group
Ravalli group
\end{abstract}

Eight zones of Precambrian stromatolites that are useful spread and extend into neighboring regions, and others occur area.

Only the Conophyton zones have been mapped in the park

The present study uses a classification based upon the three criteria of (1) mode of growth, (2) gross form of the colony, and (3) nature and orientation of the laminae. The scheme of classification also seems applicable to Paleozoic and later stromatolites. Possibly a consistent pattern of form-genera and form-species may be developed. Four form-genera and seven form-species are recognized in the Belt series of the park region. These are Oryptozoon occidentale Dawson, Collenia undosa Walcott, $O$. frequens Walcott, $O$. symmetrica Fenton and Fenton, Newlandia sp., and Conophyton inotinatum n. sp.

It is realized that these structures should not be classified according to biological nomenclature. However, biological names are here applied to the structures until a suitable system of classification can be devised.

Comparisons of the stromatolites of the Belt series with modern stromatolites on Andros Island, Bahama Islands, and Pleistocene stromatolites from Lake Lahonton, Nev, reveal similarities in structure that appear to be significant as to physical mode of origin.

\section{INTRODUCTION}

\section{PREVIOUS INVESTIGATIONS}

The precambrian stromatolites of the Belt series were first recognized by C. D. Walcott, and in 1906 he published photographs of an algal structure for which the name Cryptozoon frequens was proposed. (See pl. 20, fig. 6.) In 1914, Walcott published descriptions of several genera and species of Precambrian stromatolites. Many of Walcott's "algae" have since been considered to be of inorganic origin (Fenton and Fenton, 1936). However, later studies agree with Walcott's belief in the algal nature of several of the species he described, especially some of those he referred to the genus Oollenia.

From 1911 to 1914, field parties of the Geological Survey under the supervision of $M$. R. Campbell made extensive geologic studies and mapped a large part of Glacier National Park. Although at first they did not recognize the stromatolites as organic structures, their many references to gnarly and concretionary limestones have been a great aid in locating outcrops of stromatolite beds.

Very little attention was given the stromatolites of the Belt series until the period between 1927 and 1936 . During this time C. L. and M. A. Fenton devoted five field seasons to the study of the paleontology and stratigraphy of the Belt series. The results of their investigations were published between 1931 and 1943 in papers cited.

\section{PRESENT INVESTIGATION}

The present investigation was begun in 1951 as a part of a project on the Belt series of northwestern Montana, under the direction of C. P. Ross, and has continued to the present time. During the early stages of his mapping, Ross recognized that several beds in the Belt series of Glacier National Park, Mont., contained structures of probable algal origin. A few of the beds or zones appeared to be persistent over rather wide areas, and one zone in the Siýeh limestone was mapped. Later, a zone in the Missoula group was also mapped. Owing to the small map scale, it was not possible to map any of the other zones.

The primary purpose of the present investigation was to determine if these zones could be used as stratigraphic markers. In such a great thickness of strata, where the only basis for correlation has been lithology, 
the geologist would welcome any paleontologic aids to subdivision and correlation. Local datum markers would also be useful for correct interpretation of some of the more complex structural features involving rocks of the Belt series. In addition, an ecological study of the stromatolite beds could furnish information that might be used in interpreting the paleogeography of Belt time. These uses of stromatolites have been proved in the Glacier National Park region.

As a result of these studies it was found possible to group the several growth forms of the stromatolites into a fewer number of "specific" categories, to rearrange "generic" assignments more systematically, and to define the "genera" and "species" more precisely.

\section{AREA OF INVESTIGATION}

Most of the detailed work has been carried out in the Glacier National Park region, but a part of it has been done in other localities in northwestern Montana and northern Idaho. (See fig. 49.) Stromatolites were found at each locality. It appears that the Belt series in those areas is susceptible of subdivision on the basis of stromatolite zones.

In the Coeur d'Alene district, Idaho, stromatolites have been noted in the Prichard formation and the Burke formation. Possibly detailed work will uncover stromatolite zones that will be useful as key horizons in other formations of the district. In the vicinity of Troy and Libby, Mont., stromatolite beds accur in the Wallace and Striped Peak formations. Near Helena, Mont., the Helena limestone, Spokane shale, and the Greyson shale have yielded stromatolites. In the Big Belt and Little Belt Mountains stromatolites have been reported in the Spokane shale, Greyson shale, and Newland limestone.

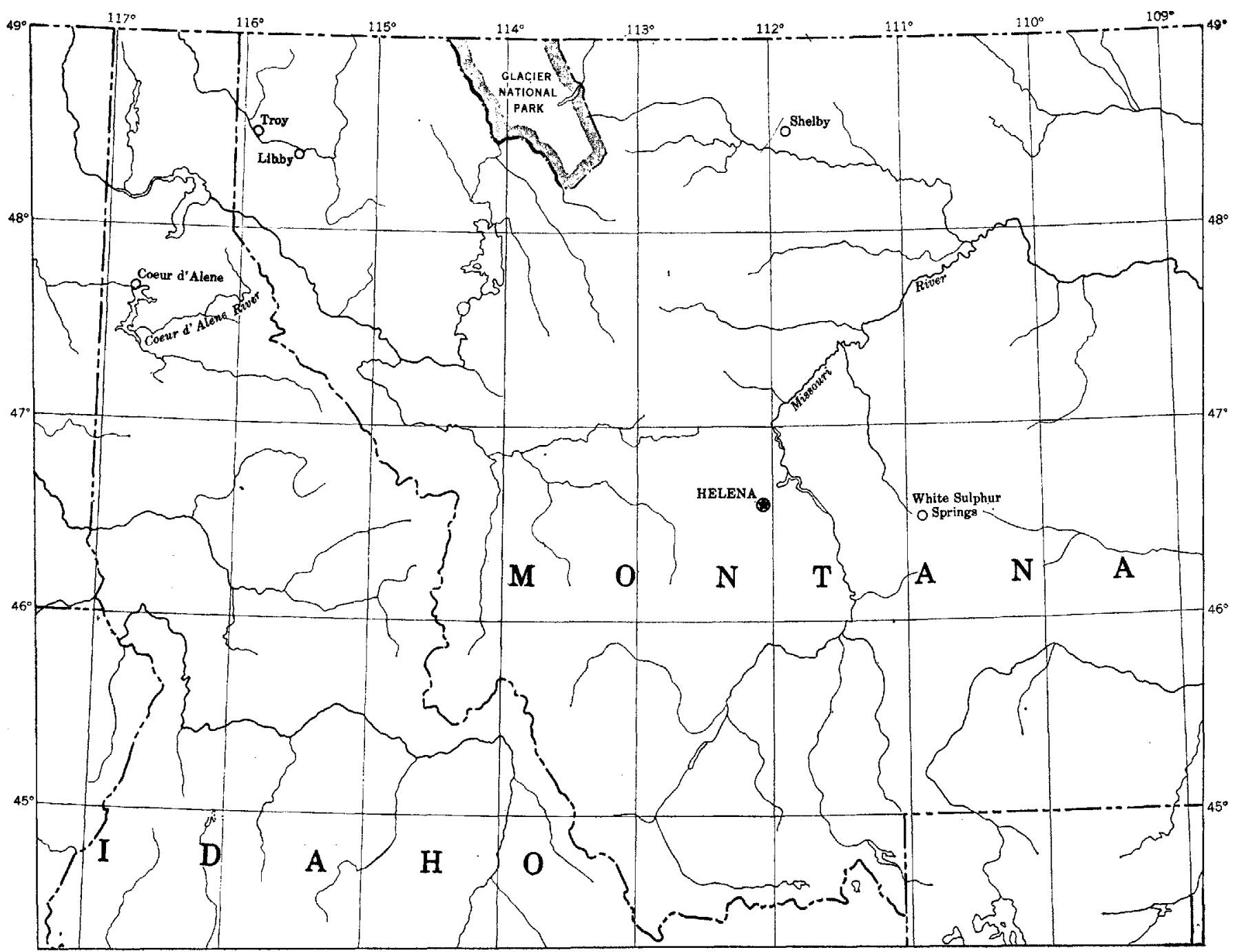

100 Miles

FfoUre 49.-Map of northwestern Montana and adjacent States, showing area of investigation and localities mentioned in text. 


\section{ACKNOWLEDGMENTS}

It is a pleasure to acknowledge my indebtedness to the many persons who have contributed to the successful completion of this investigation. M. E. Beatty, chief naturalist, and Don Robinson, assistant chief naturalist, were especially helpful in placing at my disposal the Park Service facilities at Glacier National Park. Arthur B. Campbell guided me to stromatolite localities in the Coeur d'Alene district, Idaho. Prof. Adolf Knopf of the University of California and Montis R. Klepper showed me exposures of stromatolites near Helena, Mont. During the 1952 and 1953 field seasons, Robert N. Oldale ably assisted me in the field. Prof. John L. Rich of the University of Cincinnati and Prof. Erling Dorf of Princeton University allowed me to examine type specimens in their museums. Robert $\mathrm{N}$. Ginsburg showed me Recent stromatolites on some of the keys in Florida Bay. G. E. Lewis, Sergius Mamay, and J. Harlan Johnson have read the manuscript and contributed many valuable suggestions.

\section{CLASSIFICATION OF STROMATOLITES}

\section{GENERAI}

The term "stromatolite" (Kalkowski, 1908, p. 68) has been generally accepted as applying to laminated structures attributed or possibly attributable to the work of blue-green (or green) algae. Gurich (1906, p. 7) proposed the name Spongiostromidae [sic] for a family of laminated forms from the Visean limestone of the Namur Basin of Belgium. He considered the possibility of their algal affinity $(1906$, p. 31$)$ but rejected the idea in favor of referring the forms to the Protozoa. Later writers have indicated that the Spongiostromidæ are probably calcareous algae. Julius Pia (1927, p. 36) used the family name "Spongiostromata" as a major division of the class Schizophyceae (Cyanophyta) and divided the family into two parts. Under "Stromatolithi" he included all forms, such as the genera Collenia Walcott, Cryptozoon Hall, and Spongiostroma Gurich, that grew attached to the substratum. The second division he called "Oncolithi," and in it he included unattached forms, such as the genera Osagia Twenhofel, Pyonostroma Gurich and Ottonosia Twenhofel. This grouping appears to be valid and its retention seems to be desirable.

The present study discriminates between fossil algae and stromatolites. Fossil algae preserve recognizable organic microstructures that enable the examiner to determine their true biologic relationships. Such microstructures include cell walls, reproductive organs, and other parts. The stromatolites, however, rarely exhibit recognizable microstructures beyond a fine lam- ination. They are large headlike masses of sediment that have come into existence through the work of certain lowly forms of algae. The remains of the algae that built the structures are only exceptionally preserved (Tyler and Barghoorn, 1954, p. 606; Woodring, 1954, p. 222). All that is ordinarily left of the algae to attest to their original presence are the stromatolites.

There have been basic differences of opinion among authors regarding the use of generic and specific names for stromatolites. O. A. Høeg (1929, p. 8) states:

There are two facts rendering it preposterous to create names for these structures, however useful such names may be: We cannot be sure that identical coenoplases [colonies] are not formed by systematically widely different organisms; and in most cases, the coenoplases will certainly come into existence through the cooperation of more [than one] species.

P. E. Cloud, Jr., (1942, p. 363, 366) concurs with Høeg and suggests that as a matter of convenience the familiar form names be retained and used in the vernacular sense. Paul Dorn $(1953, \mathrm{p} .36)$ refuses to recognize any classification of stromatolites. R. B. Young (1933, p. 32), who has contributed greatly to the knowledge of stromatolites in South Africa, states:

Since stromatolites are as a whole devoid of organic structure, their position in any scheme of botanical classification can be justified only on the grounds of analogy with calcareous structures *** produced by known algae. The generic and specific names sometimes applied to stromatolites have avowedly little or no systematic value.

As early as 1906, H. M. Seely (1906, p. 170), in discussing the genus Cryptozoon, writes:

Seeking a place for them [Cryptozoon] in classification they are found to fall outside of any of the described orders. ** * Yet they are very distinct. They have a character of their own and they properly demand recognition. In a system of classification a place must be sought for them.

C. D. Walcott $(1914$, p. 107) in his pioneer paper on the stromatolites of the Belt series, states:

All of the genera and species are based on variation in form ***. In the absence of the identification of the actual algae that built up the structure found in the fossil state a purely artificial classiffeation has been adopted.

\section{J. H. Johnson (1946, p. 1089) states:}

They [stromatolites] may comprise form genera and form species rather than true biologic genera and species. Fach form genus and species may represent several biologic species, or even a number of genera and species that lived in constant close association. Such associations, however, permit recognition of the colonies over wide areas through appreciable lengths of geologic time. Different assemblages formed colonies sufficiently different to be separated by megascopic characteristics.

Authors who have used names for stromatolites without justifying their use include F. M. de Almeida (1944) ; Lucien Cahen, A. Jamotte, and G. Mortel- 
mans (1946); Georges Choubert (1945, 1952) ; Georges Choubert, R. Du Dresnay, and J. Hindermeyer (1950) ; Riuji Endo and C. E. Resser (1937) ; A. Jam-otte (1944a, 1944b) ; V. P. Maslov (1937a, 1937b, 1938, 1939a, 1939b) ; Nicolas Menchikoff (1946); A. Meyer (1954) ; Julius Pia (1927) ; M. R. S. Rao (1949); W. H. Twenhofel (1919); and others.

Alfred Riedel (1953, p. 674) suggests a compromise. He favors the retention of generic names, such as Collenia and Conophyton, to be used to designate geometric forms but to have no biological significance.

C. L. Fenton (1943, p. 105 and 106) comments:

For generations cryptogamic botanists have been naming genera and species of lichens despite the fact that every lichen consists of a fungus and an alga. Some 15,900 of these "improprieties" are now established in botanical literature. Surely they form ample precedent for paleobotanical species of comparable nature $* * *$. As has been pointed out, recognition of genera and species among stromatolites rests primarily on the stability of their characters. It is well displayed by generally similar forms that do not intergrade, by forms that persist through thick formations despite sedimentary variations, and by those that have wide geographic range in clearly delimited horizons.

Stromatolites offer great promise for interpreting ecological relationships in sediments that are otherwise lacking in fossils. Also it has been found (Maslov, 1939b; Riedel, 1953; Fenton and Fenton, 1937; Rezak, 1953; Cahen, Jamotte, and Mortelmans, 1946; and others) that some of these fossils are useful in local correlation. It is evident that names should be applied to these structures. The rules for paleobotanical nomenclature (Lanjouw, 1952, p. 64) define a formgenus as "one that is maintained for classifying fossil specimens that lack diagnostic characters indicative of natural affinity but which for practical reasons need to be provided with binary names." A plant taxonomist might validly object to the application of this principle to stromatolites on the basis that stromatolite species do not represent biologic entities.

In the present paper, I have used the names of formgenera and form-species with the understanding that the classification is purely artificial and is used as a matter of convenience. However, I am aware of the possibility of confusing these names with the names of biological entities. Perhaps a new method of classifying these structure should be devised. This new method should not be based upon specimens from restricted geographic localities or geologic range but should result from a comprehensive examination of all kinds of "algaloid" structures from all parts of the geologic column. Also, if we are to separate the stromatolites from biological nomenclature, their new names should not have resemblance to biologic names. Such a project is beyond the scope of the present paper. It would probably require several years to devise and perfect a new nomenclatural system.

\section{PREVIOUS CLASSIFICATIONS}

Reasons for great differences of opinion on how best to classify stromatolites are (1) lack of agreement as to the diagnostic basis for classification, (2) the impractically detailed systematic breakdown of some units that are here recognized as single, and (3) the fragmentary nature of the types of some species.

The stromatolites of the Belt series have been classified on the basis of form because of the apparent lack of microscopic organic structures. However, no statement as to what constitutes a form-genus or form-species of stromatolite is to be found in the published record. Some authors simply state that they are dealing with form-species (Walcott, 1914, p. 104; Fenton and Fenton, 1937, p. 1941). This has led to wide variation in the number and nature of recognized stromatolites.

To complicate matters, many so-called varieties of species have been erected. In many instances it has been found, by visiting sites in the field and examining types in museums, that the reason for the description of varieties is the incorrect orientation of natural sections. A vertical section through a colony of Collenia frequens Walcott shows the form of the colony to be a cylindroid, whereas a diagonal section through the same colony gives the appearance of an expanding column or turbinate form, such as Cryptozoon occidentale Dawson. If the two sections are found in two closely associated colonies, an observer may arrive at the erroneous conclusion that the expanding column is a variety of the columnar form. In other examples the reason for erecting varieties has been the discovery of a different form in rock units that are made up almost entirely of one species (Fenton and Fenton, 1933b, p. 1142). Even though the different form answers to the description of a previously described species, it has been described as a variety of the species with which it is associated. The creation of these varieties causes the interpretation of many descriptions of species to be purely a matter of personal preference, and the geologist who attempts to identify the species in the field experiences great difficulties.

The fragmentary nature of the types has proved to be a major stumbling block in comparison of specimens. Gross form of colonies is of major importance in distinguishing species, yet it is often impractical to collect complete colonies for type specimens. Some colonies attain diameters of 15 to 20 feet and weigh several tons. As a consequence, some of the types do not exhibit the diagnostic characteristics of the species. 
Therefore it is important that a photograph of the complete colony as it appears in the field be published in addition to the photograph of the holotype.

\section{PRESENT CLASSIFICATION}

\section{GENERIC DISTINCTION}

'I'wo genera of stromatolites from the Belt series of northwestern Montana that have been described by Walcott $(1914$, p. 104, 110) are Collenia and Newlandia. He describes Collenia as "More or less irregular domeshaped, turbinate or massive, laminated bodies that grew with the arched surface uppermost." In describing the species Newlandia concentrica, Walcott states that it includes "Semispherical bodies built up of concentric layers of irregular thickness that appear to be attached at the base of each cup-shaped concentric layer." He comments further (1914, p. 111): "The resemblance between the structure of Collenia and Cryptozoon is marked in the hand specimens $* * *$ but when we compare the mode of growth we find that Collenia has an encrusting-like growth that forms a dome-shaped body with the edges lamellae pointing downward, while Cryptozoon grows in a cup-shaped form with the edges of the lamellae on the upper surface."

J. H. Johnson (1952, p. 54) does not agree with Walcott's comment. He observes: "Walcott's statement that 'Cryptozoon grows in a cup-shaped form with the edges of the lamellae on the upper surface' is not true except in a few rare cases. Usually in both genera the laminae are thickest on the top and curve downward. In other words they are arched." This leaves the reader wondering just how it is possible to distinguish between these genera. Walcott's statements regarding Aewlandia and Cryptozoon are puzzling, and Johnson's comment creates doubt as to the validity of Walcott's genera. Walcott's concept of the mode of growth of Cryptozoon was apparently based upon observations of bedding surfaces in which the upper portions of the colonies had been planed off.

James Hall (1883, pl. 6), in his original description of the genus Cryptozoon, states: "A further examination shows the entire form of these masses to be hemispheric or turbinate, with the broadest face exposed upon the upper. surface of the limestone layer, [and shows] that their growth has begun from a point below and rapidly expanding upwards, has often extended one or two feet in diameter." (See also Goldring, 1937, p. 530.)

Walcott (1914, p. 113) describes the genotype Collenia undosa as "laminated bodies that are usually concavo-convex. They appear very much as though the underside had been dug out or that the first en- crusting calcareous deposit was made over a lump of mud. The interior of the body is made up of alternating fine and coarse laminations subparallel to the upper and lower surfaces of the body." Walcott's original description of Newlandia has already been cited.

It is now evident that Cryptozoon, Collenia, and Newlandia can be distinguished by their different modes of growth.

Mode of growth is the basis of generic distinction here adopted. Four distinet types of growth are recognized.

The first is typical of the genus Cryptozoon Hall. All species begin their growth from a point on the substratum and grow upward by the addition of convex upward laminae that increase in area as the colony develops.

The second type is exhibited by the genus Collenia Walcott. All the species begin as incrustations on a surface of the substratum. Growth is upward by the addition of convex upward laminae that do not increase greatly in surface area.

The third type is typical of the genus Newlandia Walcott. Here also the growth begins from a surface on the substratum, but it differs from Collenia by the addition of concave upward or saucer-shaped laminae.

The fourth type of growth is displayed by the genus Conophyton Maslov. Here the structure is cylindroidal, composed of laminae in the form of inverted nested cones. The cylindroids are attached to the substratum by the apex of the basal cone. The long axes of the cones are inclined at some angle to the bedding surfaces.

Because oncolites (unattached forms) are not known to exist in the Belt series, their classification is not discussed. Environments in which oncolites may develop are described in the section on modern environments.

\section{SPFCHFIC CHARACTERISTICS}

\section{GROSS FORM OF COLONY}

Gross form of colony is of primary importance in determining species. The basic forms are cylindroidal, depressed spheroidal, and turbinate. However, combinations of these forms are recognized as distinct species. For example, Gollenia mattiflabella 11 . sp. is made up of two basic forms. The lower part of the colony consists of rarying numbers of expanding columns. The upper part of the colony is dome shaped and completely covers the lower part. This gives the entire colony the form of a depressed hemispheroid. Cryptozoon occidentale Dawson is an example of the turbinate form. It develops into toplike structures in which the diameter is approximately equal to the height of the colony. 


\section{NATURE OF THE LAMINAE}

The nature of the laminae is an important although difficult characteristic to use in distinguishing species. Attempts have been made to measure the number of laminae per unit distance on several species, both on weathered surfaces and in oriented thin sections. However, these studies have not been encouraging and have been discontinued.

Ordinarily, the shape of the laminae is reflected in the gross form of the colony. An example of this is Collenia symmetrica Fenton and Fenton, in which the laminae are parallel to the upper surface of the colony. There are, however, exceptions to the rule. Cryptozoon occidentale Dawson has a fan-shaped vertical cross section, but the laminae in the younger part of the colony are dome-shaped, becoming flattened as the colony increases in size. The flattened laminae are abruptly downcurved along their margins, and each one is but slightly larger than the one below it, giving rise to the fan-shaped cross section.

Laminae may also be smooth or crenulate. The regularity of the laminae seems to be consistent within each species. Conophyton inclinatum n. sp. and Cryptozoon occidentale Dawson exhibit smooth laminae, Collenia multiflabella n. sp. and Collenia symmetrica Fenton and Fenton have finely crenulate laminae, and Collenia undosa Walcott has coarsely crenulate laminae.

\section{SIZE OF DOLONY}

Size of colonies has been used by some authors as a specific characteristic, but, in my experience, size varies in each species and only form and laminae remain constant. In Glacier National Park, colonies of Conophyton inclinatum n. sp. range in size from a few inches to about 48 inches across the base of the cone. In other areas gigantic forms of Collenia symmetrica Fenton and Fenton have been observed. The largest colonies of this species in the Glacier National Park region are about 6 feet in diameter. In the Helena limestone, near Helena, Mont., the species attains diameters of 15 to 20 feet.

\section{TYPES}

In the following descriptions of species, citations of museums and collections in which types and figured specimens are located are abbreviated. The abbreviations are as follows:

USNM-U. S. National Museum, Washington 25, D. C. UCM-University of Cincinnati Museum, Cincinnati, Ohio. PUM-Princeton University Museum, Princeton, N. J.

USGS-U. S. Geological Survey algae collection; Palentology and Stratigraphy Laboratory, Denver Federal Center, Denver, Colo.

\section{KEY TO THE IDENTIFICATION OF STROMATOLITES} IN THE BELT SERIES

The key that accompanies plate 19 (following p. 154) has been devised to serve as an aid to the identification of stromatolites in the Belt series. However, it is possible that it may be expanded to include all stromatolites. For this reason, the key has not been condensed but contains steps that may aid in the classification of some forms as yet unnamed. Plate 19 includes photographs of the seven species here recognized.

\section{DESCRIPTIONS OF GENERA AND SPECIES}

\section{Genus CRYPTOZOON Hall, 1883}

Oryptozoon Hall, 1883, N. Y. State Mus. Ann. Rept. 36, pl. 6.

Genotype: Cryptozoon proliferum Hall, 1883.

Generic diagnosis.-Colonies begin growth from a point on the substratum and grow upward by the addition of convex upward laminae. Gross form is depressed hemispheroidal or turbinate.

\section{Cryptozoon occidentale Dawson (emend. Rezak)}

Plate 20, figure 5; plate 21, figures 1, 2, 3

Cryptozoon occidentale Dawson, 1897, Canadian Rec. Sci., $\mathbf{\nabla} .7$, p. 208 , fig. 3.

Cryptozoon occidentale Dawson. Walcott, 1899 , Geol. Soc. America Bull., v. 10, p. 233, pl. 23.

Collenia occidentale (Dawson). Walcott, 1914, Smithsonian Misc. Coll., v. 64, p. 111, pl. 15, figs. 1-6.

Collenia compacta Walcott, 1914, Smithsonian Misc. Coll., $\nabla .64$, p. 112 , pl. 15, fig. 7 .

Fenton and Fenton, 1931, Jour. Geology, v. 39, p. 684, pl. 8, fig. 2.

Specific diagnosis.-Colonies subcircular in plan; fanshaped in cross section, range in height from a few inches to 6 feet; maximum width about equal to height. Laminae smooth; dome-shaped in younger parts becoming flattened at crest and incurved around margins as colony grows larger. Each lamina slightly larger than preceding one, giving rise to fan-shaped cross section.

Syntypes.-USNM 60710, 60711.

Type site.-Grand Canyon, Ariz.

Occurrence.-Chuar group, Grand Canyon region; upper Grinnell argillite, upper Siyeh limestone, and occasionally in argillites of the Missoula group.

Remar7s.-Walcott $(1899$, p. 233$)$ was obviously undecided as to whether $C$. occidentale should be included in Collenia or Cryptozoon. Later (1914, p. 111), he transferred the species to the genus Collenia, explaining that Cryptozoon occidentale grew much in the same way as Collenia undosa "except that owing to its being crowded together it grew to a greater height from a 
narrow base." He did not mention that the colonies were not crowded until after they had attained considerable height. Because of the fact that $C$. occidentale began its growth from a point on the substratum, it is here referred to the genus Cryptozoon. Walcott (1914, p. 111) also remarked on the resemblance of Collenia compacta to $C$. occidentale, the only difference being that $C$. compacta developed laminated growths between the club-shaped individuals. Laminated growths between individual colonies are quite common in fossil stromatolites and are not here regarded as specific characteristics. Actually, the holotype of $C$. compacta does not show the entire structure of the colony. In examining Walcott's specimens and later collections, the structure described in the specific diagnosis is readily seen.

Genus COLIENIA Walcott, 1914

Oryptozoon Hall. Walcott, 1906, Geol. Soc. America Bull., v. 17, pl. 11.

Collenia Walcott, 1914, Smithsonian Mise. Coll., v. 64, p. 110.

Genotype: Collenia undosa Walcott, 1914.

Generic diagnosis.-Colonies begin as incrustations on a surface of the substratum and grow upward by addition of convex upward laminae. Gross form cylindroidal or hemispheroidal.

\section{Collenia undosa Walcott}

Plate 21, figures $4,5,7,8$

Oollenia undosa Walcott, 1914, Smithsonian Misc. Coll., v. 64, p. 113, pl. 13, figs. 1, 2 ; pl. 14, figs. 1, 2.

Fenton and Fenton, 1931, Jour. Geology, v. 39, p. 684, pl. 6, pl. 7, figs. 3,5 .

Fenton and Fenton, 1987, Geol. Soc. America Bull., v. 48, p. 1947 , pl. 11, figs. 3,4 ; pl. 14, fig. 3.

Collenia willisii Fenton and Fenton, 1937 [in part], Geol. Soc. America Bull., v. 48 , p. 1945 , pl. 11, fig. 1 ; pl. 12, figs. $4,5,6$.

Specific diagnosis.-Colonies expand upward to form hemispheroidal bodies. Sizes range from 1 inch in height and 2 inches in diameter to 18 inches in height and 20 inches in diameter. Laminae coarsely crenulate and rather strongly convex upward. Colonies expand upward with growth and unite laterally with others to form biostromes with striking mammillate surfaces.

\section{Holotype.-USNM 60707.}

Type site.-Eight miles west of White Sulphur Springs, at forks of Birch Creek, Meagher County, Mont.

Occurrence.-Spokane shales near White Sulphur Springs, Mont.; Grinnell argillite and lower Missoula group in Glacier National Park.

Remarles.-In examining the holotype of Collenia willisii Fenton and Fenton, 1931 (PUM 24020), I found it to be a part of a colony of Collenia undosa Walcott, 1914. Other members of the species $C$. willisii are here referred to Collenia multiflabella n. sp.

\section{Collenia frequens Walcott}

Plate 20, figures $1,2,3,4,6,8,9,10,11$

Cryptozoon frequens Walcott, 1906, Geol. Soc. America Bull., v. 17 , pl. 11.

Collenia? frequens (Walcott). Walcott, 1914, Smithsonian Misc. Coll., v. 64, p. 113, pl. 10, fig. 3.

Collenia columnaris Fenton and Fenton, 1931, Jour. Geology, v. 39, p. 682 , pl. 1-2.

Fenton and Fenton, 1937, Geol. Soc. America Bull., v. 48, p. 1941 ; pl. 9 , figs. 1,2 .

Collenia versiformis Fenton and Fenton, 1937, Geol, Soc America Bull., v. 48, p. 1947; pl. 14, fig. 2 ; pl. 16, fig. 4 ; pl. 18, figs. 1 and 2.

Collenia olbertensis Fenton and Fenton, 1937, Geol. Soc. America Bull., v. 48, p. 1942, pI. 11, fig. 2.

Collenia expansa Fenton and Fenton, 1987, Geol. Soc. America Bull, v. 48, p. 1948, pl. 16, fig. 1, 3.

Specific diagnosis.-Widely spaced to closely crowded cylindroidal colonies that stand at angles of $50^{\circ}$ to nearly $90^{\circ}$ to bedding surfaces. Colonies from 2 inches to 15 inches in diameter and from 6 inches to 23 feet in height. Laminae smooth, strongly convex to flattened, not normally weathered into strong relief.

Type.-USGS a117 (by subsequent designation).

Type site.-Railroad cut along Bear Creek opposite mouth of Devil Creek.

Occurrence.-Altyn limestone, Siyeh limestone, and limestone lenses in the Missoula group.

Remarks.-Walcott published the species $C$. frequens in 1906, using a photograph without a description. The photograph was taken by Bailey Willis in 1901, and his caption reads: "Rock mass showing large concretionary or coralline masses in the Siyeh formation about 500 feet from the top of the formation. Head of McDonald Creek. Ridge between McDonald and Logging Creeks near the summit." Walcott, however, made no mention in his original paper of the site where the photograph had been taken. Later, (1914, p. 113) he gave the locality as "Little Kootna Creek (Waterton River), Chief Mountain Quadrangle, Montana." During the 1953 field season, an unsuccessful attempt was made to find the type site. In the general area of the site described by Willis, the Conophyton zone 1 was found to occur about 500 feet below the top of the Siyeh limestone. Subzone $A$ of this zone contains well-developed cylindroidal colonies. Walcott's original illustration and later description of this species indicates without a doubt that the colonies assumed a cylindroidal form at right angles to the bedding surfaces. The Fentons describe $O$. frequens as being 
conical in form, mistaking it for Conophyton Maslov which is so abundant in the zone.

Collenia multiflabella n. sp.

Plate 21, figure 6; plate 22, figure 1

Collenia willisii Fenton and Fenton, 1937 [in part], Geol. Soc. America Bull., v. 48, p. 1945; pl. 10, figs. 1 and 3.

Specific diagnosis.-Colonies roughly circular in plan, hemispheroidal, range up to 3 feet in height and 5 feet in diameter. Laminae finely crenulate, flattened at crest, give appearance of fine mammillae on upper surfaces of colonies. Basal part consists of variable number of cylindroids expanding upward and capped by later laminae that are continuous over the columns. Slight downflexing on the laminae at the margins of the colonies.

Holotype.-USGS a118.

Type site.-Logan Pass, Glacier National Park, Mont.

Occurrence-Collenia multiflabella zone in the upper Siyeh limestone.

Remarks.-The specific name refers to the expanding cylindroids in the basal part of the colonies. In natural vertical sections the cylindroids have a fanlike appearance. The Fentons have mistaken representatives of this species for Callenia undosa Walcott. The holotype and some of the paratypes of Collenia willisii Fenton and Fenton were collected from float near Iceberg Lake, and are believed to have weathered out of the Collenia undosa zone 2 some distance above their zone of Collenia willisii, and here are referred to the species $C$. undosa.

The reference to plate 13 , figure 1 , under the species Collenia willsii Fenton and Fenton (1937, p. 1945) is incorrect. The explanation of plates identifies the figure as Collenia clappii n. sp., which is here regarded as a subjective synonym of Collenia symmetrica Fenton and Fenton.

\section{Collenia symmetrica Fenton and Fenton}

Plate 22, figures $3,4,5,6,7,8$

Collenia symmetrica Fenton and Fenton, 1931, Jour. Geology, v. 39, p. 683 , pl. 3-5.

Fenton and Fenton, 1937, Geol. Soc. America Bull., v. 48, p. 1942 , pl. 10, fig. 2 ; pl. 13, fig. 1.

Collenia clappii Fenton and Fenton, 1937, Geol. Soc. America Bull., v. 48, p. 1948, pl. 14, fig. 1.

Collenia parva Fenton and Fenton, 1937, Geol. Soc. America Bull., v. 48 , p. 1948, pl. 14, flg. 4 .

Specifio diagnosis.--Colonies 1 inch to approximately 20 feet in diameter and one-half inch to 10 feet in height; depressed hemispheroidal; subcircular in plan. Laminae smooth to finely crenulate, flattened centrally but sharply downfolded at margins of colony.
Holotype.-UCM 7703.

Type site.-Cut Bank Pass, Glacier National Park, Mont.

Occurrence-Grinnell argillite, Siyeh limestone, and Missoula group.

Remarks. $-C$. symmetrica seems to have developed on newly submerged mud flats. It is ordinarily found upon a mud-cracked surface, and large amounts of associated breccia indicate agitation of the surrounding water. The only difference between $C$. symmetrica, $C$. clappii Fenton and Fenton, and $O$. parva Fenton and Fenton is in dimensions. The Fentons do not include dimensions in their description of $O$. symmetrica. However, they state that $C$. parva ranges from 12 to 17 millimeters in diameter and $O$. clappii from 5 to 105 centimeters in diameter. Size is here considered not to be a specific characteristic, and the three forms are regarded as the same.

\section{Genus NEWLANDIA Walcott, 1914}

Newlandia Walcott, 1914, Smithsonian Mise. Coll,, v. 64, p. 104.

Genotype: Newlandia frondosa Walcott, 1914.

Generic diagnosis.-Incrusting colonies that grew upwards from a surface on the substratum by addition of concave upward laminae.

\section{Newlandia lamellosa Walcott \\ Plate 23, figure 8}

Newlandia lamellosa Walcott, 1914, Smithsonian Misc. Coll., v. 64, p. 106 ; pl. 10, figs. 1, 2.

Specifio diagnosis.-Bowl-shaped to cup-shaped colonies from 1 inch to approximately 15 inches wide and from 1 to 10 inches high. Laminae smooth, concave upward; less concave than lower surface of colony.

Holotype.-USNM 60702.

Type site-At forks of Little Birch Creek, about 8 miles west of White Sulphur Springs, Mont.

Occurrence.-Newland limestone at type site, possibly Grinnell argillite in Glacier National Park region and Burke formation in Coeur d'Alene district, Idaho.

Remarks.-The original description of the genotype $N$. frondos $a$ and the fragmentary nature of the specimens used to illustrate the form give very little information on the mode of growth of this genus. Only by comparing my specimens with those classified by Walcott as $N$. lamellosa did the mode of growth and the gross form of Newtandia become apparent. WaIcott described his species of Newlandia as "frond-like." The term is misleading because Newlandia, like Collenia and Cryptozoon, is an incrusting form and not frondlike.

Specimens collected in Glacier National Park and the Coeur d'Alene district have been doubtfully re- 
ferred to this genus. The form is somewhat similar to the form of Newlandia, but the laminae are much more strongly concave and seem to parallel the lower surface of the stromatolite. (See pl.23, fig. 7.) Some of these specimens are associated with probable slump structures, which makes their organic origin doubtful.

\section{Genus CONOPHYTON Maslov, 1937}

Conophyton Maslov, 1937b, Moscow Univ. Lab. Paleontology Pub., Problems of paleontology, v. 2-3, p. 344, pl. 4, figs. 2,3 .

Genotype: Conophyton lituus Maslov, 1937.

Generic diagnosis.-Cylindroidal colonies composed of nested conical laminae. Apex of basal cone usually attached to substratum; long axis of cone inclined at some angle to bedding surfaces.

Remarks.-Similar structures have been reported in the Otavi Mountains of South Africa (Schwellnus and le Roex, 1945). These, however, are vertically disposed with reference to the bedding and always point downward. R. B. Young (1940, p. 17-21) described conical structures in the limestones of the Dolomite series in the Transvaal. These are in the form of inverted cones similar to those in the Otavi system. V. P. Maslov (1937b, p. 344) described conical forms in the lower and middle Cambrian of the Aldan river and western Baikal regions, U. S. S. R., in which the apices are directed upwards. Maslov (1938, p. 330) later referred to forms reported by V. N. Makhayev from the Maia river region-forms that grow with the apex pointing downward and commonly are perpendicular to the bedding but may be inclined. It seems reasonable to assume from the field evidence in northwestern Montana and the descriptions of occurrences in South Africa and the U. S. S. R. that the colonies grew with the apices of the cones attached to the sea bottom. The significance of the anomalous orientation of the apices of the Aldan river material is not known at this time. Maslov did not mention his concept of the mode of growth in his original diagnosis. However, the strong resemblance between his illustrations of Conophyton and the material from the Belt series seems sufficient to allow the use of the name Conophyton for these specimens.

\section{Conophyton inclinatum n. sp. \\ Plate 23, figures $1,3,5,6,9$}

Collenia frequens Walcott. Fenton and Fenton, 1931, Jour. Geology, v. 39, p. 685, pl. 8, fig. 1 .

Fenton and Fenton, 1933, Geol. Soc. America Bull., v. 44, p. 1135-1142, fig. 2 , pl. 57 .

Fenton and Fenton, 1937, Geol. Soc. America Bull, v. 48, p. 1946, pl. 15, figs. 1, 2.

Specifie diagnosis.-Cylindroidal colonies consist of array of nested cones; inclined at low angles to bedding surfaces. Apical angle averages about $40^{\circ}$. Diameters range from 2 inches to 48 inches and a verage about 8 inches. Lengths up to 3 feet, but some may be greater. Laminae conical, concentric, and smooth.

Syntypes.-USGS a2, a283, a284.

Type site.-Just west of snowshed 6, Great Northern Railway, opposite the point where Devil Greek flows into Bear Creek, Glacier National Park, Mont.

Occurrence.-Conophaton zone 1 in the Siyeh limestone and the Conophyton zone 2 in the Missoula group. Conophyton does not occur outside these two zones in the area described in this report.

Remarks.-The specific name was selected because of the inclined position of the cones with reference to the bedding surfaces. Conophyton lituus Maslov differs from Conophyton inolinatum $\mathrm{n}$. sp. in the position of the apex of the cone. In Conophyton liture Maslov, the apex points upwards. Maslov mentions (1937b, p. 344) that Conophyton lituus occurs with Collenia in the Lower and Middle Cambrian of the U. S. S. R. It is therefore assumed that the stromatolite occurs in a normal sequence of strata and the anomalous orientation of its apex is not due to an overturned sequence of beds.

\section{STRATIGRAPHY \\ GENERAL}

Detailed stratigraphic descriptions of the major units of the Belt series in the area under consideration will be given in a forthcoming paper by C. P. Ross ${ }^{1}$ and will not be repeated here.

Stromatolites are known to exist in each of the major units of the Belt series in the Glacier National Park region except the Appekunny argillite. (See fig. 50.) Eight distinct zones occur in the area. Not all stromatolites, however, are restricted to these zonles: Many isolated bioherms and small biostromes occur at random throughout the section. By far the greater number of these fossils is found in the carbonate rocks, but the stromatolites are not restricted to this type of lithology. It has been noted that some argillites and even quartzites contain stromatolites. Each of the 8 zones is characterized by the dominance of 1 or 2 species, and 7 of the zones are known to persist throughout the park and the areas to the south and west of the park.

The names of the zones are taken from the species that occurs in greatest abundance. For example, the Conophyton zone 1 consists primarily of Conophyton inclinatum n. sp., but this is not the only species that

1 Ross, C. P., Geology of Glacter National Park and the Flathead region, northwestern Montana-t. S. Geol. Survey Prof. Paper 296 (in preparation). 
may exist in that zone. Collenia frequens Walcott, Collenia multiflabella n. sp., and Cryptozoon occidentale Dawson also occur but in lesser quantities.

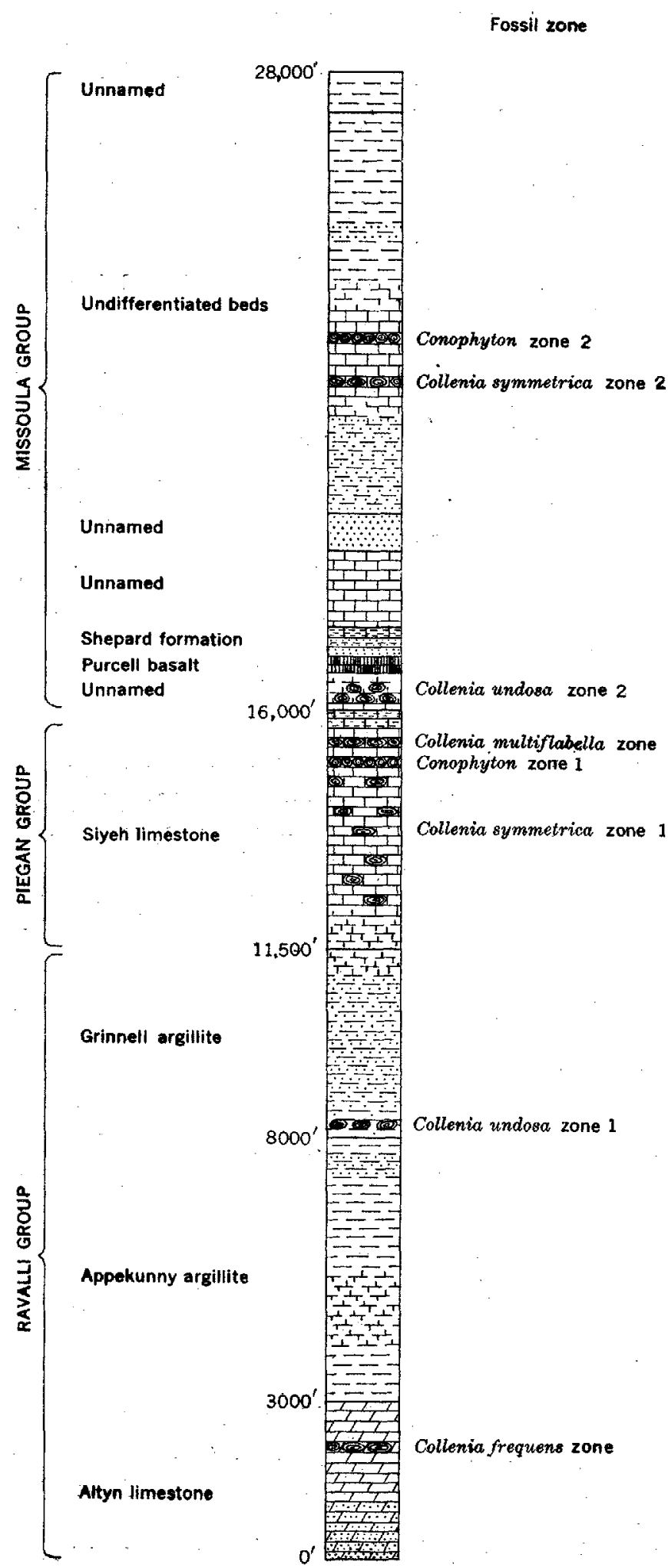

Figure 50,-Stromatolite zones in Glacier National Park.

\section{STROMATOLTTE ZONES}

\section{RAVALLI GROUP}

ALTYN LIMESTONE

COLLENIA FREQUENS ZONE (C. COLUMNARTS ZONE OF FENTON AND TENTON)

The Fentons (1931, p. 676) describe the zone as a "massive, light gray, limestone in a single bed some 20 feet thick, and virtually the entire mass of stone is formed by the colonies of this one alga." In a later paper (1937,p. 1833) they describe the zone as occurring in the upper part of their Hell Roaring member of the Altyn limestone. According to the Fentons, "the uppermost Hell Roaring beds are massive, light gray, dolomitic limestones interbedded with edgewise mud breccias and lenses of dolomitic sandstone or conglomerate; their thickness averages 85 feet. Massive beds are crowded with Collenia columnaris ( $C$. frequens) **'*. They form the Collenia columnaris zone." The zone is reported to extend from the vicinity of Appekunny Falls in the Many Glacier area southward to Spot Mountain at the entrance to Two Medicine valley. I have examined the zone at the type site (Appekunny Falls) and on Divide Mountain. At both localities it is very well developed and fits the description given by the Fentons in 1937. Elsewhere the zone is either less conspicuous or entirely lacking. The very narrow outcrop belt- of the Altyn limestone and the fact that the formation is cut by numerous minor thrusts associated with the Lewis overthrust may account for the fact that the zone is missing in some localities.

\section{GRINNEIL ARGILITTE}

Before the summer of 1953 , stromatolites were not known to exist in the Grinnell argillite. During that summer two occurrences were discovered.

The first discovery was made at the west end of Bad Rock Canyon along the tracks of the Great Northern Railway: A 3- to 4-foot-thick bed of greenish-gray dolomitic argillite contains small structures that have been doubtfully referred to the genus Newlandia. These fossils are similar to forms in the Prichard formation in the Coeur d'Alene district to the west. However, slump structures were recognized near some of the stromatolites and their organic origin is questionable.

COLLENIA UNDOSA ZONE 1

The second discovery was made on Going-to-the-Sun Highway in St. Mary valley about 0.3 miles east of the bridge across Baring Creek. There, a 10-inch bed of green argillite contains stromatolites identified as $\mathrm{Col}$ lenia symmetrica Fenton and Fenton, Cryptozoon occidentale Dawson, and Collenia undosa Walcott. The 
bed occurs about 200 feet above the base of the formation. It is quite similar to the beds of the Collenia un dosa zone in the lower part of the Missoula group, except that the biostrome in the Grinnell occurs in a section consisting chiefly of reddish-brown sandstone interbedded with green argillite. It was not possible to determine the areal extent of these zones because they were found late in the last season of field work. How- ever, it is possible that they are as extensive as the other zones in the area and they may serve as useful horizon markers within the Grinnell argillite when more detailed investigations are conducted.

The following table illustrates the relative stratigraphic positions of the zones as compared with the stratigraphic column described by Fenton and Fenton (1937, p. 1880-1890).

\begin{tabular}{|c|c|c|c|}
\hline \multicolumn{4}{|c|}{ Ravalli group } \\
\hline \multicolumn{2}{|c|}{ Fenton and Fenton (1937) } & \multicolumn{2}{|c|}{ This paper } \\
\hline Formation & Member & Algal zone & Formation \\
\hline \multirow{3}{*}{ Grinnell argillite } & Rising Bull & & \multirow{3}{*}{ Grinnell argillite } \\
\hline & Red Gap & & \\
\hline & Rising Wolf & Collenia undosa zone 1 & \\
\hline \multirow{3}{*}{ Appekunny argillite } & Scenic Point & & \multirow{3}{*}{ Appekunny argillite } \\
\hline & Appistoki & & \\
\hline & Singleshot & & \\
\hline \multirow{3}{*}{ Altyn limestone } & Carthew & & \multirow{3}{*}{ Altyn limestone } \\
\hline & Hell Roaring & C. frequens zone & \\
\hline & Watertun & & \\
\hline
\end{tabular}

\section{PIEGAN GRoUP}

SIYEH LTMESTONE

COLLENIA SYMMETRICA ZONE 1 (COLLENIA AYMMETRICA ZONE OF FENTON AND FENTON)

This zone, the thickest in the area, extends from the base of the Siyeh limestone to the base of the Conophyton zone 1 (fig. 50). Its thickness ranges from 2,500 to 3,000 feet. The zone differs from the others in that it does not contain widespread biostromes. The stromatolites occur at random throughout the zone as isolated colonies or thin, discontinuous biostromes. Collenia symmetrica is the dominant form in the zone, but occasional colonies of Collenia multiflabella $\mathrm{n}$. sp. may also be found. The stromatolite beds seem to be restricted to the fine-grained black-and-tan-laminated argillaceous limestones. Associated with the stromatolites are beds of edgewise breccia containing fragments of algal colonies. (See pl. 22, fig. 5.)

Many beds in the Collenia symmetrica zone 1 and other limestones in the section contain so-called segregation structures that lend an unusual appearance to weathered surfaces. (See pl. 20, fig. 7.) Some of the structures consist of irregular lenticles of relatively pure limestone contained in a matrix of dolomite. Hilary Bauerman $(1885$, p. 26 ) first described the structures and named them "molar tooth" because of their resemblance to the markings on the molar teeth of elephants. Daly (1912, p. 73-76) also used the term "molar tooth" and stated that they were formed by segregation along cleavage planes at high angles to the bedding surfaces. The Fentons (1937, p. 19271928) agreed with Daly in their idea that segregation occurred long after lithification. The structures probably assumed their present appearance at the time of the Lewis overthrust.

Fenton and Fenton assigned this zone to the lower 500 to 900 feet of the Siyeh limestone and separated it from the Conophyton zone 1 with their Goathaunt member. In the present investigation $I$ have found that the Fentons' Goathaunt member contains Cotlenia symmetrica Fenton and Fenton in about the same frequency of distribution as the Collenia symmetrica zone 1 . Consequently, the zone is here extended to include the Goathaunt member of the Fentons.

The type site of the zone is on the ridge forming Cut Bank Pass, between the Cut Bank and Dry Fork valleys, Glacier National Park. The zone is extensive 
and may be seen wherever the lower part of the Siyeh limestone crops out. in the park area. It has been traced as far west as the upper access road to Hungry Horse Dam.
The following table illustrates the relative stratigraphic positions of the zones as compared with the stratigraphic column described by Fenton and Fenton (1937, p. 1890-1900).

Piegan group

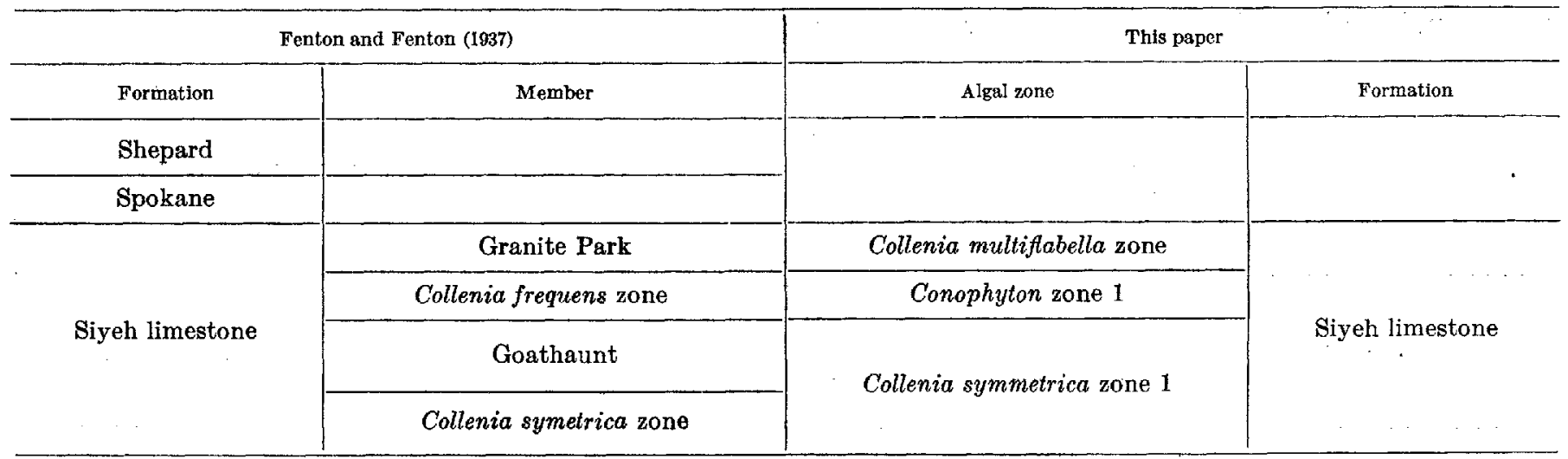

CONOPHYTON ZONE 1 (COLLENIA FREQUENS ZONE OF FENTON AND FENTON)

This is the most conspicuous zone in the park. (See pl. 18.) It forms a massive layer of dark-gray crystalline to fine-grained limestone that may be seen from a great distance. The early workers in the area referred to the zone as the "massive bed" before its algal origin was suspected. Fenton and Fenton called it the Collenia frequens zone, thinking that the conical form so abundant in the zone is what Walcott described as Collenia frequens. Where the zone shows the densest growth of stromatolites, Conophyton inclinatum n. sp. is most abundant, with Cryptozoon occidentale Dawson, Collenia frequens Walcott, and Collenia multiflabella n. sp. occurring in subordinate amounts. Along The Garden Wall the zone may be subdivided as follows:

Subzone $O$ (top of zone): Cryptozoon occidentale Dawson and Collenia multiflabella n. sp., abundant heads; Conophyton inclinatum. n. sp., occasional colonies

Subzone B: Conophyton inclinatum n. sp., large biostromes and small podlike bioherms

Subzone A: Collenia frequens Walcott, biostrome

Feet

Subzone $B$ thins gradually toward the west and is completely absent in the Whitefish and Flathead Ranges.

Where Conophyton inclinatum $\mathrm{n}$. $\mathrm{sp}$, occurs in biostromes, the colonies are closely packed, and no detrital material is apparent between the individuals. The podlike bioherms range in size from 5 feet to 22 feet in width and up to 6 feet in height. They contain closely packed colonies of Conophyton inclinatum n. sp., measuring from a few inches to 4 feet in diameter. Each bioherm has associated with it a variable thickness of finely laminated black and tan limestone. The laminae are continuous from the colonies on the margins of the bioherms and are apparently offreef algal mats. All the observed offreef deposits dip towards the west and are overlain by other bioherms. An excellent exposure of one of these bioherms and associated offreef deposits may be seen in the road cut 6.4 miles northwest of Logan Pass.

The type site of this zone is on the eastern slope of Swift-current Pass on the Granite Park trail. The zone is on The Garden Wall near Haystack Butte, along Going-to-the-Sun Highway just below Logan Pass on both sides of the pass, and on the highway 6.4 miles northwest of the pass.

\section{COLLENIA MULTIFLABELLA ZONE}

Fenton and Fenton (1937, p. 1896) describe their Granite Park member of the Siyeh limestone as: "Magnesian limestones, oolites, argillites, and quartzites [that] represent the final stage of Siyeh sedimentation. Large colonies of Collenia willisii n. sp. are abundant at several horizons."

The Collenia multifabella zone coincides roughly with the Granite Park member of Fenton and Fenton (1937). It contains Collenia multiflabella n. sp. and Cryptozoon occidentale Dawson in large biostromes that are up to 6 feet thick. Conophyton does not occur 


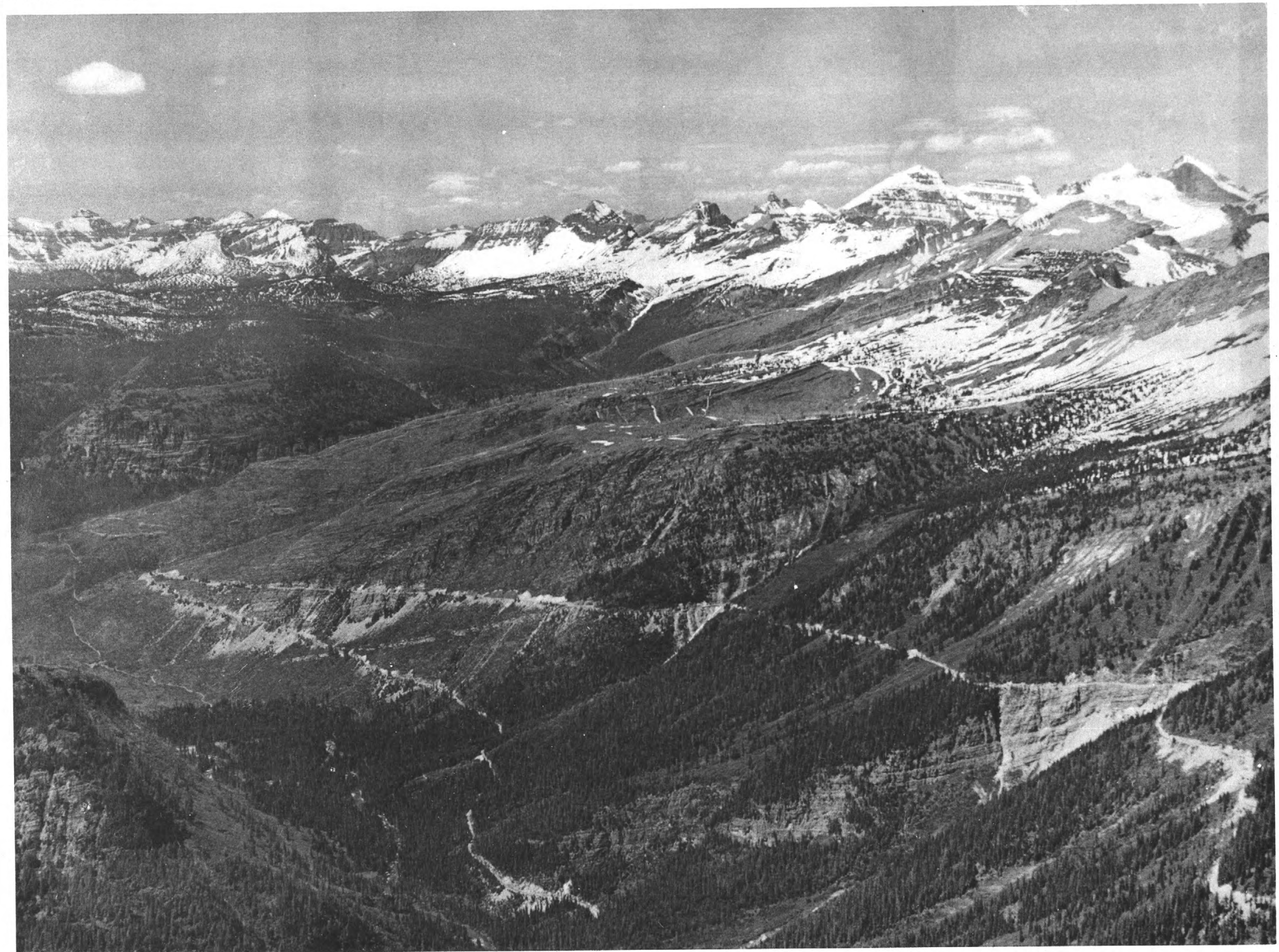

OUTCROP OF CONOPHYTON ZONE 1 IN MCDONALD VALLEY McDonald valley and The Garden Wall as seen from the top of Mount Oberlin. The Conophyton zone 1 can be seen crossing Going-to-the-Sun Highway at two points. The 100 -foot zone appears as a narrow light-colored
band crossing diagonally just below the center of the photograph. 
in the zone, although Fenton and Fenton (1933b, p. 1136) refer to bioherms of that form in their Granite Park member. The boundary they draw between their Granite Park member and their Collenia frequens zone falls within subzone $O$ of the Conophyton zone 1.

The type site of the Collenia multiflabella zone is on Logan Pass near the point where the north fork of Reynolds Creek plunges into St. Mary valley. The zone is well exposed above the highway on both sides of the pass.

\section{MISSOULA GROUP}

COLEENIA UNDOSA ZONE 2

The lower few hundred feet of the Missoula group consists chiefly of alternating red and green argillite and subordinate thin beds of pink limestone. The thickness of the unit varies appreciably over the area described in this report. However, the unit is easily recognized at all localities. In the vicinity of Logan Pass it is about 400 feet thick. The limestone beds average 1 foot in thickness and, although none has great lateral extent, together they are numerous enough to be recognized over a large area. The biostromes are crowded with colonies of Collenia undosa Walcott, Collenia symmetrica Fenton and Fenton, and Cryptozoon occidentale Dawson. Of the three species, Collenia undosa Walcott occurs in the greatest abundance. The colonies are composed of alternating layers of pink limestone and green argillite. On the fresh rock surfaces they present a spectacular appearance with the structure of the laminae made especially conspicuous by the alternating colors. On weathered surfaces the laminae show strong relief, owing to the differential weathering of the limestone and argillite layers.

The type site of the Collenia undosa zone 2 is near the base of Mount Oberlin at Logan Pass. At the type site, 8 biostromes of Collenia undosa Walcott were found. Other localities where the zone is well exposed are 0.2 mile east of the big switchback on The Garden Wall, 0.6 mile northeast of the lower end of Lake McDonald, and 1.2 miles south of Walton, Mont., on U. S. Highway 2.

\section{COLLENIA SYMMETRICA ZONE 2}

The upper half of the Missoula group is exposed only in the southwest part of the park and in the Flathead region to the south of the park. Elsewhere in the area it has been removed by erosion. Along the east side of the valley of the Middle Fork Flathead River, south of Riverview Mountain, a sequence of red and green argillite and quartzite is overlain by a limestone that is very similar in lithology to the Siyeh limestone. The field party of M. R. Campbell mapped these two units as Grinnell argillite and Siyeh limestone. In 1932, C. H. Clapp (1932, pl. 4) published a geologic map that included this area. On his map the units are designated "Grinnell argillite" and "Newland limestone." For both, it is necessary to postulate a steeply dipping fault extending up the valley of the Middle Fork Flathead River and separating the socalled Grinnell argillites on the east side of the valley from argillites of the Missoula group on the west side. Fenton and Fenton (1937, p. 1900) accepted this interpretation. However, in the course of the field work for the present report, no evidence was found to confirm the presence of this fault. Also, stromatolites were found in the argillites on the east side of the valley that indicate a Missoula age for those beds. In addition to this evidence, the stromatolite zones in the limestone differ considerably from those in the Siyeh limestone just a few miles to the east. The entire sequence lies conformably upon argillites of the Missoula group in the Flathead Range.

Collenia symmetrica zone 2 occurs about 6,000 feet above the base of the Missoula group in the area described above. The zone is about 50 feet thick and is made up of 3 biostromes of Collenia symmetrica Fenton and Fenton. Cryptozoon occidentale Dawson and Collenia frequens Walcott occur in minor numbers.

Section of Collenia symmetrica zone 2, measured just west of the tunnel at Singleshot, on the Great Northern Raithoay tracks along Bear Oreek

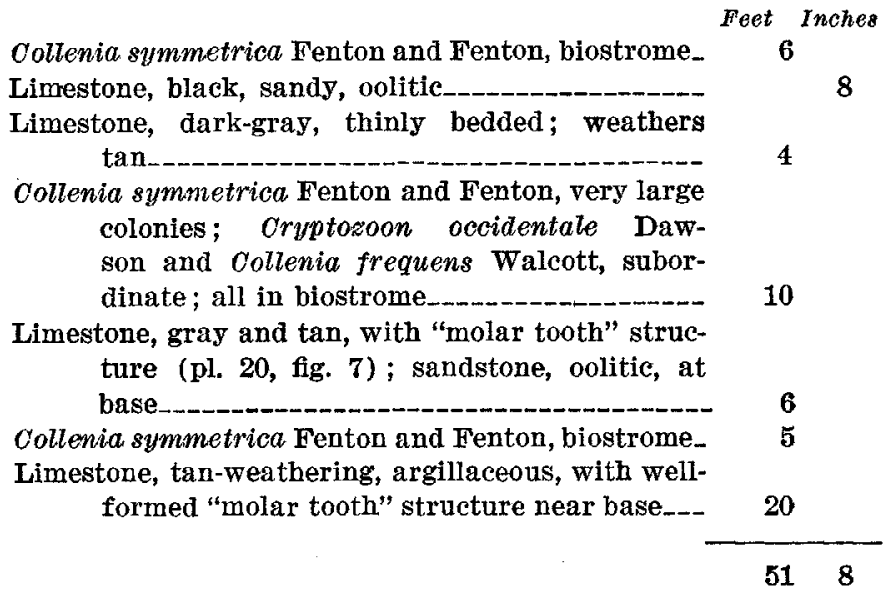

The following table illustrates the relative stratigraphic positions of the zones as compared with the stratigraphic column described by Fenton and Fenton (1937, p. 1900-1903). 
Missoula group

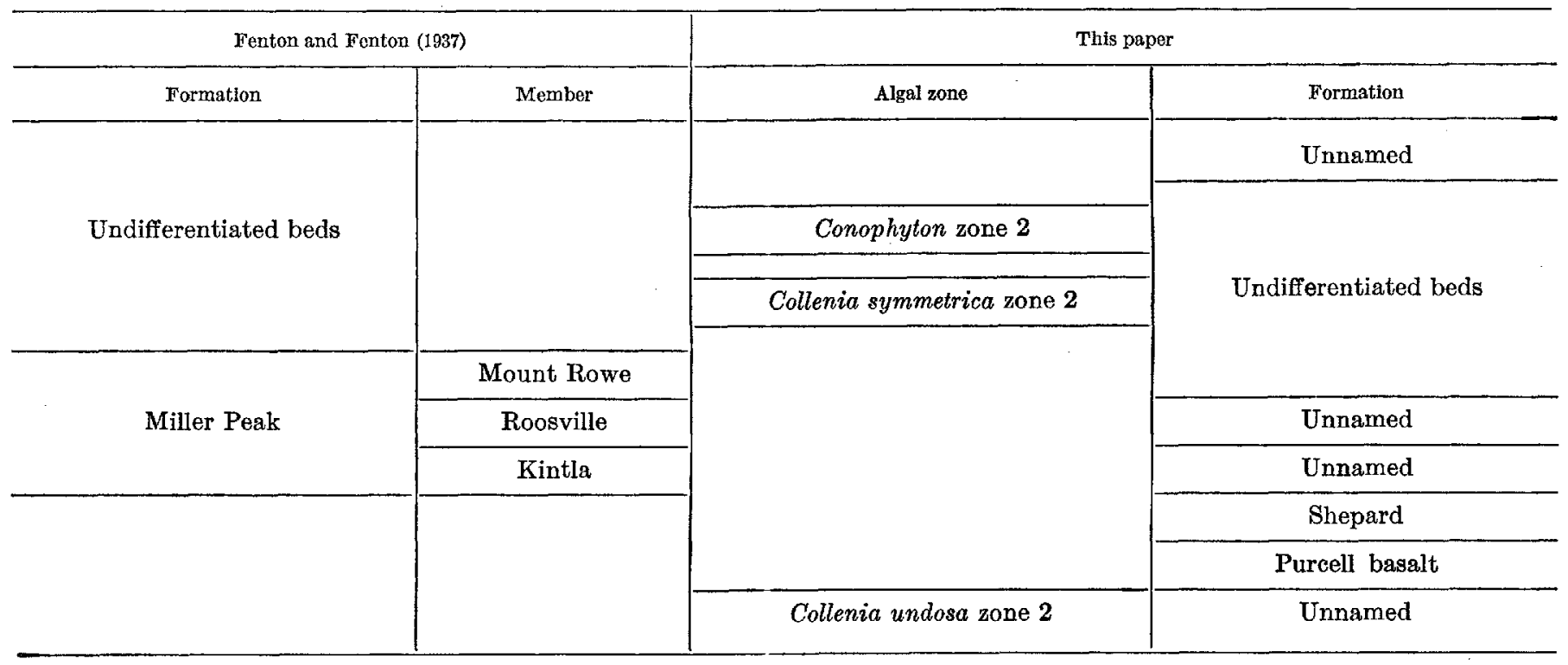

The Collenia symmetrica zone 2 differs from its counterpart in the Siyeh limestone in thickness and the lateral persistence of the biostromes. Zone 2 is much more compact vertically than zone 1 . In the Siyeh limestone, no continuous beds of Collenia symmetrica Fenton and Fenton have been found. However, in the Missoula group the species forms widespread biostromes that are easily recognized in widely separated outcrops.

The zone is known to extend from Riverview Mountain on the east side of the Middle Fork Flathead River, southward to a point a quarter of a mile west of the mouth of Cabin Creek on the Middle Fork Flathead River, a distance of about 20 miles. It may also be seen on both sides of the valley of Bear Creek. The type locality of the zone is just west of the tunnel at Singleshot, on the Great Northern Railway tracks along Bear Creek.

$$
\text { CONOPHYTON ZONE } 2
$$

A second zone of Oonophyton occurs approximately 400 feet above the Collenia symmetrica zone 2 . It is similar to its counterpart in the Siyeh limestone when viewed from a distance. The zone averages about 100 feet in thickness and has the same massive character as the Conophyton zone 1. The elements of the zone, however, are considerably different. Conophyton inolinatum n. sp. and Collenia frequens Walcott are the only species that occur in the zone. Their distribution within the zone is constant over a large area. The following section is typical of the zone in the southern half of the mapped area. (See pl. 25.)
Section of the Conophyton zone 2, on hillside above trail opposite mouth of Cy Oreek, NE1/4 sec. 35 , unsurveyed T. $28 \mathrm{~N}$., $\boldsymbol{R}$. 15 W., Flathead National Forest, Mont.

Subzone E: Conophyton inclinatum n. sp., closely packed, biostrome; colonies up to 2 feet in diameter........

Subzone $D$ : Collenia frequens Walcott, well-developed, biostrome; colonies up to 15 inches in diameter and 6 feet in height_._- 6

Subzone $C$ : Limestone, barren, black, shaly__.______._. 11

Subzone B: Conophyton inclinatum, $\mathbf{n}$. sp., closely packed, biostrome-_-__-_-_-_-_-_-_-_-_-_- 35

Subzone A: Collenia frequens Walcott, biostrome; only slightly weathered; laminae do not stand out in relief; colonies average 4 inches in diameter and 23 feet in height

The zone has been mapped for 20 miles along the strike and 7 miles along the dip. (See pl. 25.) From the Cy Creek locality to Running Rabbit Mountain the subzones are remarkably uniform in thickness and composition. However, from Running Rabbit Mountain northward to the northwest flank of Riverview Mountain, subzones $B$ and $E$ thin rapidly and subzones $A$ and $D$ thicken. The total thickness of the zone remains about the same. At Riverview Mountain the zone dips under Tertiary alluvium and its northern limits are unknown. The southern limits of the zone were not explored, owing to the inaccessibility of the area and the limitation of time.

The type locality of the zone is at the top of Running Rabbit Mountain, in the southwestern corner of Glacier National Park. The zone on the western slopes of 
Scalplock, Rampage, and Riverview Mountains may be viewed from U. S. Highway 2, between Essex and Pinnacle. A good distant view is also afforded from the highway along Bear Creek between Java and Fielding. Here the zone is exposed on the south slopes of Running Rabbit, Snowslip, and Blacktail Mountains. An excellent exposure of the zone occurs at the pass between Giefer Creek and Twenty-five Mile Creek, on the west side of Baldhead Mountain.

\section{ECOLOGY}

Stromatolites occur in rocks ranging in age from Precambrian to Recent. Recent occurrences provide a basis for interpreting the conditions favorable for their development. As stromatolites are not the actual remains of algae but structures that were developed by the reactions of the organisms to their physical environment, they are, in effect, a reflection of the environment in which they developed. The physical laws that govern the reactions of matter to changes in temperature, salinity, moisture content, and other conditions presumably operated during the Proterozoic in the same manner as they do today. Thus, although many of the modern stromatolite-forming algae are able to exist under a wide range of environmental conditions, others are restricted to certain combinations of environmental factors. In the following discussion an attempt will be made to lay the groundwork for interpreting the possible conditions of origin of the stromatolites studied-it is not intended, of course, to set forth strictly limiting environmental factors for each species.

\section{MODERN ENVIRONMENTS}

Two areas in which modern stromatolites have been reported to be developing in marine and near-marine environments are southern Florida (Ginsburg, ${ }^{2}$ 1954, 1955) and Andros Island, Bahama Islands (Black, 1933). During the fall of 1954 and the spring of 1955 , I visited these areas in order to obtain firsthand information on the occurrences.

Maurice Black (1933), in his paper on the algal sediments of Andros Island, describes in detail the distribution of marine algae on and near that island. $\mathrm{He}$ also comments on the similarity of the modern stromatolites to structures existing in Precambrian and Paleozoic sedimentary rocks. The following table lists the four algal zones on Andros Island as reported by Black.

\footnotetext{
a Ginsburg, R. N., and others, 1954, Laminated algal sediments of south Florida and thelr recognition in the fossil record: Univ. Miams Marine Lab., Coral Gables, Fla., unpub. manuseript.
}

Algal zones on Andros Island

[After Black, 1933]

\begin{tabular}{|c|c|c|}
\hline $\begin{array}{c}\text { Maxl- } \\
\text { mum } \\
\text { salinity } \\
\text { (parts per } \\
\text { thou- } \\
\text { sand) }\end{array}$ & Nature of habitat & Flora \\
\hline $30-40$ & Shoal water below tides............. & Chlorophycea: Udotea, Penicillus, \\
\hline $15-36$ & Between tides near high water- & Cyanophyceae: Phormidium, Sym- \\
\hline Trace-2 & $\begin{array}{l}\text { Above high watermark, inland } \\
\text { marl flats. }\end{array}$ & $\begin{array}{l}\text { Cyanophyceas: Scytonema, Plec- } \\
\text { tonema, Schizothrix, and unicel- }\end{array}$ \\
\hline 0 & $\begin{array}{l}\text { Above high watermark, limestone } \\
\text { outerops. }\end{array}$ & Scytonema alone. \\
\hline
\end{tabular}

In the shoal-water habitat, Black observed no complex algal heads, and the Cyanophyta which are responsible for these structures are not present in large numbers. The predominant algae in this habitat are the Chlorophyta, which bind the sediment without producing any laminated structure. Black remarks (1933, p. 169) that it was only above low water mark, where the Cyanophyta are the prevalent algae, that the alga controlled lamination and algal heads with characteristic internal structures were found.

W. R. Taylor (1928) does not report any stromatolites in his paper on the marine algae of Dry Tortugas. However, he refers to a total of 42 species of Cyanophyta, of which 31 are littoral or sublittoral. Concerning the littoral zone, he states (1928, p. 34), "the Myxophyceae (Cyanophyta) constitute an important part (31 forms) and this zone is the only one in which they are significant."

M. A. Howe described the algal flora of Bermuda in 1918. His comments on the occurrence of Cyanophyta $(1918$, p. 491$)$ bear out the observations of Black and Taylor.

The Cyanophyta may form gelatinous or slimy dark seums on rather stagnant water or somewhat similar films or crusts on rocks or on the larger aquatic plants, either between the tide lines or permanently submerged. They are not confined to the sea, but are perhaps even more common in brackish or fresh water. They also occur on moist ground and even on the trunks of trees and rocks where rains and atmospheric moisture are their only sources of water supply.

My own observations of the distribution of Cyanophyta along the seashore are in agreement with those of Black, Taylor, and Howe. Marine Cyanophyta are most abundant above low watermark. In this zone, only those algae capable of surviving long periods of drought and considerable changes in salinity are able to exist. It is on the moist ground and rocks in and above this zone that stromatolites are most likely to develop.

Black described 4 types of algal deposits on Andros Island. All these deposits were found developing above 
low watermark. In southern Florida, Ginsburg ${ }^{3}$ reports 2 types of algal deposits that coincide with 2 of Black's types. The simplest, type $A$ of Black and type $I$ of Ginsburg, occur in areas frequently inundated by seawater (intertidal zone near high watermark). Filamentous blue-green algae permeate the sediment as it is deposited and bind it together. At times of nondeposition, a thin algal mat is formed. The alternation of these organic layers merely accentuates the mechanically formed laminae. The alga does little else to modify the sediment. (See fig. 51.) domes and that they are only seasonal features. However, distortions in the subsurface laminae are probably due to old domes. Bubblelike distortions have been observed in finely laminated sedimentary rocks of the Belt series and later deposits.

According to Black, the most highly developed types of algal head and the most extensive algal deposits are found bordering the fresh-water lakes in the interior of Andros Island. Along the margins of these lakes are large areas of limy mud marshes that are covered by algal heads that exhibit nearly concentric laminae. De-

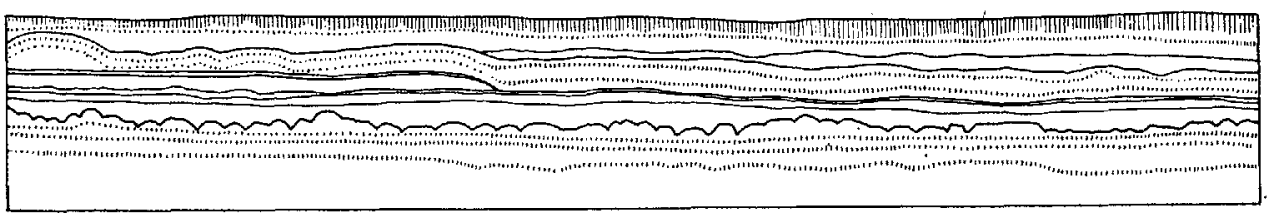

Figdra 51.-Algal deposits of type $A(\times 2)$ (after Black, 1933 ).

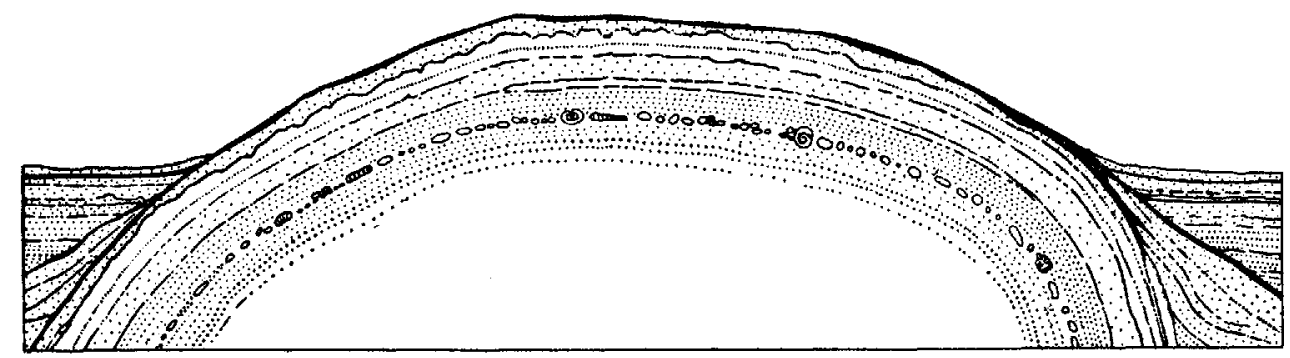

Figdrn 52.--Algal deposits of type $B(\times 1)$ (after Black, 1933).

The sediment is composed of two types of laminae. The thicker laminae are between 0.5 millimeter and 2.0 millimeters thick and are made up of detrital grains that are up to 0.1 millimeter in diameter. Interbedded with these distinctly sedimentary laminae are thinner layers, about 0.1 millimeter thick, of very fine-grained sediment. These layers are apparently made up of the grains that were entrapped in the mucilaginous sheaths of the algae. Some of the finely laminated sedimentary rocks in the Belt series could have developed in a similar manner.

Black's type $B$ is similar to one of the forms described by Ginsburg under his type $I I$. These deposits are formed above high watermark beyond the immediate influence of shore flooding. (See fig. 52.) They are irregularly disposed hollow domes or bubbles, 1 or 2 inches in height and 4 or 5 inches in diameter. They exhibit crude concentric lamination that is due to the differences in grain size in the successive layers and to the alternation of light and dark layers in which the grains are imbedded in the remains of algae. Ginsburg ${ }^{4}$ mentioned that reflooding of the area destroys the

Op. cit.

4 Op. cit., p. 21. posits of type $C$ appear as regularly spaced raised discs, from 4 to 5 inches in diameter. Black $(1933$, p. 173) remarks:

This growth form is the result of two opposing tendencies. The growth process, by itself, gives rise to flat or smoothly convex forms similar to those of type $B$; this simple shape, however, is rarely retained for long and is constantly liable to modification during periods of partial drying. Owing to the large proportion of orgasic matter, and fine texture of the sediment in the algal heads, drying causes the upper layers of the sediment to contract and a concave shape results. [See fig. 53.] Renewed growth of the algae produces further layers, at first concentric with the older part of the algal head, but gradually re-establishing the convex form again. [See fig. 54.]

Three genera and three or four species contribute to the formation of these structures. The sediment consists of angular detrital grains of calcite averaging about 4 microns in diameter.

Deposits of type $D$ are similar to the earlier formed parts of algal heads of type $O$ except in their having a greater proportion of organic material to sediment and in the less orderly form of their laminae. During dessication they roll up and become completely detached from the substratum. (See fig. 55.) The algae of type $D$ deposits are the same as those in type $C$ but differ in proportion. The sediment is extremely fine grained; 


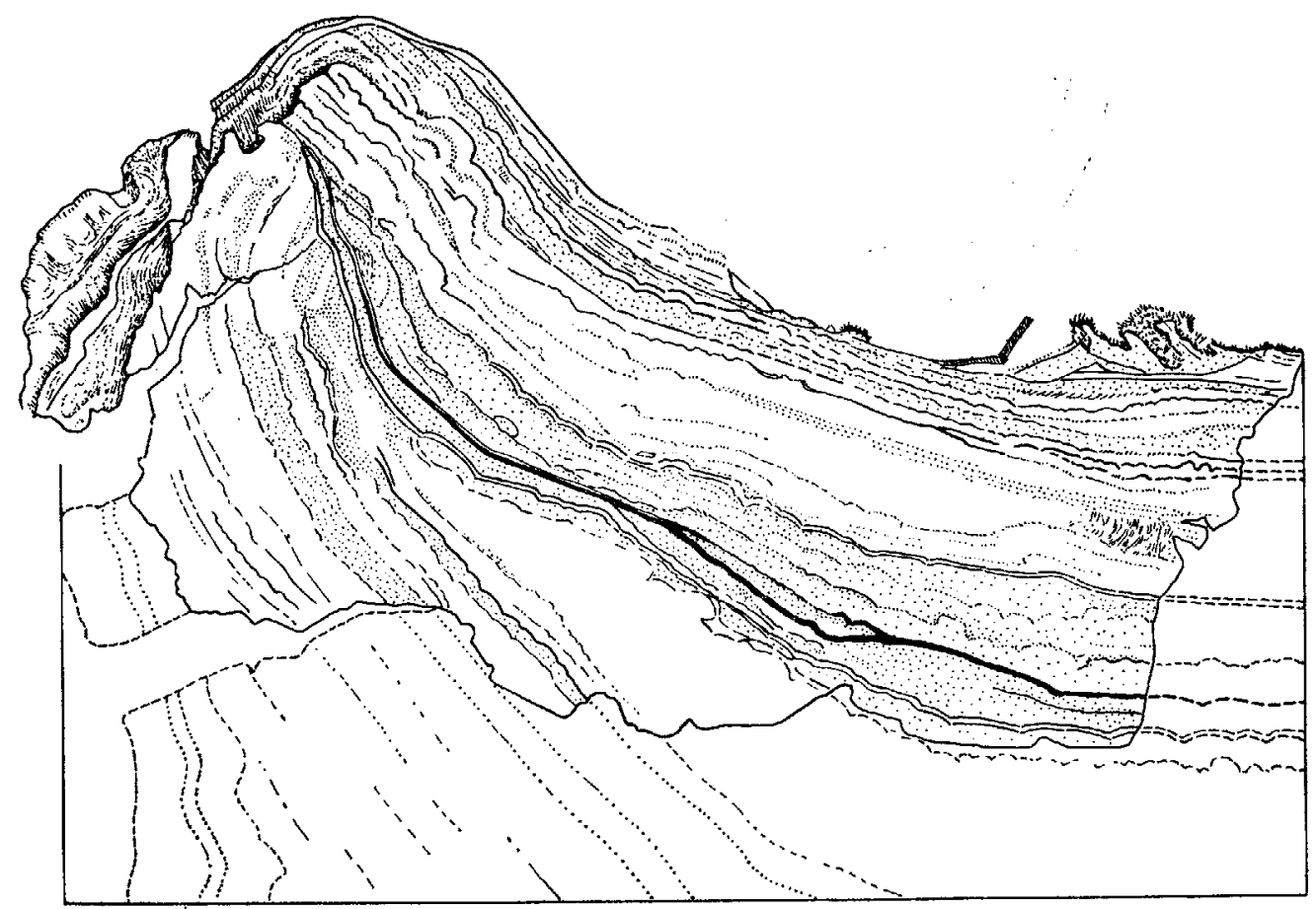

Ficure 53.-Algal deposits of type $O(\times 2)$ (after Black, 1933).


FIGURE 54.-Sequence of growth of algal deposits of type $C(\times 1 / 4)$ (after Black, 1933). 


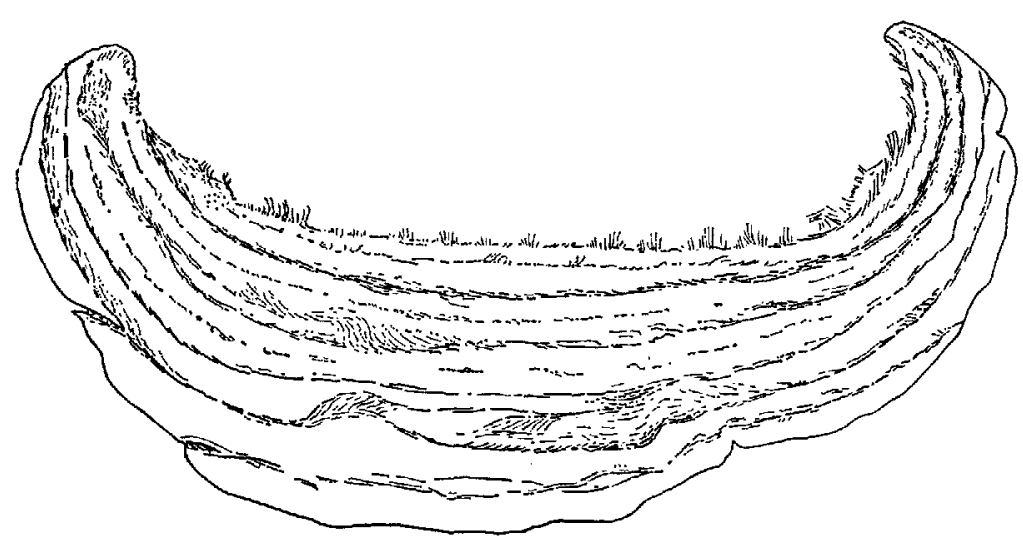

Figdra 55.-Algal deposits of type $D(\times 2)$ (after Black, 1933).

most particles are 2 microns or less in diameter. According to Black, this material is a limy mud that has been washed into the interior of the island by hurricane waves. Except for these occasional inundations of the island's interior by sea water, the algal heads in that area are soaked by rainwater and fresh ground water containing large amounts of dissolved calcium carbonate.

Structures similar to Black's types $C$ and $D$ also occur in southern Florida. Ginsburg has treated these as variants of his type $I I$. In addition to the stromatolites described by Ginsburg as developing above low tide level, he cites (1955, p. 724) the occurrence of small discrete spheroidal forms in Florida Bay at depths of 1 to 6 feet. These spheroidal forms are unattached and free to roll about on the bottom. These are onkolites similar to Ottonosia Twenhofel from the lower Permian.

Several occurrences of modern spongiostromes growing in continental environments have been described in the published record (Bradley, 1929; Clarke, 1900; Howe, 1932 ; Jones, 1925; Pia, 1933; Roddy, 1915 ; Walcott, 1914). Bradley (1929, p. 204-206) describes deposits along the shores of Green Lake, N. Y. He states, "All these deposits are exceedingly porous or spongy and consist of more or less closely intergrown arborescent masses that are richly nodose. They resemble native copper but are more profusely branched." Here, the form of the deposit is controlled by the growth habit of the algae, and it can be readily comprehended that a fine precipitate of lime is deposited about the filaments of the algae. This deposit of finely divided lime adheres to the mucilaginous sheath of the algae and is gradually built up into a spongy mass. (See pl. 24, figs. 3 and 4.) Bradley's descriptions do not fit any of the stromatolites of the Belt series.
In 1900 Clarke (1900, p. 195) published a brief paper on the water biscuits of Squaw Island, Canandaigua Lake, N. Y. He states:

The north shores of Squaw Island and the lake bottom about it and over its northward sand bar are covered with flat, whitish calcareous cakes of circular or oval shape, in size ranging from a dime to a half dollar. To pick up one of these, well dried on the surface of the island, and break it in half, seems enough to convince the reflective mind at once of their nature and mode of formation. It often contains as a central nucleus a beach pebble of shale or limestone, a twig, or a bit of charcoal from some youngster's campfire. About this a white or greenish travertine has been deposited in concentric layers, which show themselves with distinctness. The calc-carbonate being dissolved in dilute acid and entirely removed, there remains a soft spongy organic residuim of precisely the rolume of the original biscuit.

These concretionary masses grew unattached on the floor of the lake and belong to the group called Oncolithi by Pia (1927, p. 37). (See p. 129.) These masses, also, are unlike the stromatolites of the Belt series.

In 1915 Roddy (1915, p. 247) described calcareous concretions similar to those of Squaw Island from Little Conestoga Creek, Lancaster County, Pa.

Later, Howe (1932, p. 61) described similar concentrically laminated calcareous pebbles from Furnace Creek, a tributary of the Potomac River about 11/2 miles above Harpers Ferry, W. Va. Howe (1932, p. 62) states, "The first microscopic examinations of ground sections and of decalcified preparations showed a mixture of minute plants-diatoms, unicellular Chlorophyceae, unicellular and filamentous Myxophyceae [Cyanophyta], and possibly bacteria."

Pia (1933, p. 172) reports that algal crusts of the Bodensee [Lake Constance], Bavaria, yielded 12 species in 7 genera of green and blue-green algae and several species of diatoms. He states that there are many 
places on the earth where limy masses are originating through the activity of algae and these are identical with fossil forms called Cryptozoon, Pyonostroma, and others.

The monograph by I. C. Russell (1885) on the geologic history of Lake Lahonton includes several illustrations of calcareous tufa that apparently developed along the ancient shorelines. Several specimens, from recent collections in that area, have been supplied to me by Roger Morrison of the U. S. Geological Survey. Russell describes three types of tufa (1885, p. 190): "(1) Lithoid tufa; (2) Thinolitic tufa; (3) Dendritic tufa." Of these, only the thinolitic tufa appears to be of inorganic origin.

Some of the lithoid tufa is similar in structure to some of the Precambrian stromatolites. (See pl. 22, figs. 1 and 2.) The dendritic tufa resembles modern structures in Green Lake, N. Y. (See pl, 23, figs. 2 and 4.) One of the specimens from Morrison's collection is a fragment of a Recent algal mat from the shores of the Carson Sink, Nev. The mat consists of intertwined algal filaments that bind together a layer of detrital sediment. (See pl. 24, figs. 1 and 2.) Morrison states (oral communication, 1954) that the mat developed along the shores of the lake around 1860, when the level of the lake was considerably higher than at present. The level of the modern Carson Sink is quite low, and at times it dries up completely. The mat has been completely dessicated, and attempts to grow algae by placing fragments in water have been unsuccessful. According to Morrison (oral communication, 1954), such algal mats are at present forming deposits of lithoid tufa at Soda Lakes, about 9 miles northwest of Fallon, Nev. These deposits are very close to the present surfaces of the lakes and apparently are the only type of algal deposit forming at the present time. Perhaps the highly saline and alkaline composition of the lake water does not permit the growth of species that develop the dendritic tufa.

J. C. Jones $(1925$, p. 7) studied the origin of tufas in the Salton Sea and arrived at the conclusion that the tufas are the result of algal activity. Jones carried his study of modern tufas to Pyramid Lake, another remnant of Lake Lahonton, and found that tufas are forming there at the present time. The tufa consists of a thin layer covering the exposed surfaces of about half of the rocks and gravels along the shores. This thin layer extends from an elevation of 12 feet above lake level to an unknown depth beneath the surface of the lake. Jones $(1925$, p. 9) describes the distribution of algae in the lake as follows:
At the water's edge a long filamentous green alga, a species of Cladophora, grows as a fringe 6 to 9 inches long in a narrow band about equally divided above and below the water. When the level of the lake falls, this dries, bleaches, and forms a grayish-white, paper-like band clinging to the rocks. * * Below this band a grayish-white alga, another species of Cladophora, with much shorter flaments, grew in tufts and bunches that had their bases so firmly fixed in the layer of recent tufa that pulling the algae from the rocks brought the tufa layer with them. At the base of the tufts was a narrow zone of blue-green algae that included species of Oallothrix, Nostoc, and Formidium. * * * at depths of 4 feet and over, the blue-greens grew in the absence of the other algae, and in every instance in constant association with the recent tufa.

Jones further states $(1925$, p. 9$)$ that the recent tufa forms a film up to 2 or 3 millimeters thick on the surfaces of rocks-" "where the deposit is thin it can be seen to begin as a multitude of separate rounded points that rapidly increase in diameter, meet, and coalesce. As the deposit thickens it becomes solid, compact, and stony, and is a typical lithoid tufa."

Two distinct types of fossil lithoid tufa occur in the Lake Lahonton region. The first is a dense, compact, laminated structure, irregularly shaped, that appears to have been formed under water. This form is similar to the modern tufas described by Jones (1925). The second type is porous and laminated, develops regular, dome-shaped structures. (See pl. 22, fig. 2, and pl. 24, fig. 7.) This type of tufa resembles the algal structures of Andros Island and the Belt series. (See fig. 52; pl. 20, fig. 3, and pl. 22, fig. 3.) I believe that these structures might have developed above the lake level and that the lamination is due to alteration of the paperlike mat, described by Jones, and very fine detrital sediment.

The occurrences described in the foregoing discussions are outlined below according to the environments and the types of spongiostromes found in the environments. Paleoclimatic data from Lake Lahonton was furnished by Roger Morrison (written communication, 1954).

\section{Environments in which spongiostromes form}

I. Marine environments.

A. Shallow marine environments, depths of 1-6 feet.

1. Oncolites (unattached spheroidal bodies).

B. Environments that are near sea level but above low watermark.

1. Sediment-binding algae that may produce stromatolites similar to some of those of the Belt series. (See p. 141.)

C. Deeper marine environments.

1. Calcareous algae (red or green algae) exist at greater depths but these are not considered to be spongiostromes, 
Environments in which spongiostromes form-Continued

II. Continental environments.

A. Fresh-water lakes, such as Green Lake, N. Y., in which the algal deposits develop below the surface of the water. (See p. 144.)

1. Structures that are predominantly arborescent rather than stromatolitic.

2. Concretionary structures (water biscuits) that should be called oncolites rather than stromatolites.

B. Fresh-water streams, such as Furnace Creek, W. Va. (See p. 144.)

1. Predominantly concretionary structures (oncolites).

C. Lakes of the Great Basin section, such as Lakes Iahonton and Bonneville and their remnants, in which salinity varies appreciably with time. (See p. 145.)

1. Shallow lakes, saline and warm, with fluctuating lake level and generally slight wave action.

a. Beach zones (areas kept wet by wave action and extending several feet above lake level at a given time).

(1) Tufa, porous, laminated, lithoid; closely resembles the stromatolites of the Belt series.

b. Lake bottoms, shallow water.

(1) Tufa deposits, compact, laminated, irregularly shaped, lithoid. These forms only crudely resemble the stromatolites of the Belt series.

2. Deep lakes, relatively fresh cold water; fluctuating lake level; strong to weak wave action at times of tufa deposition.

a. Beach zones.

(1) Forms similar to IICla(1), above.

b. Lake bottoms, shallow to deep water.

(1) Arborescent forms similar to deposits of modern fresh-water lakes. (See II A1, above.)

The similarities between some of the lithoid tufas of Lake Lahonton and the algal deposits of Andros Island is not a surprising coincidence. Both environments are close to the level of a standing body of water and in both places the algae develop in a zone of extreme variability in salinity. The hurricane winds that occasionally drive waves across the interior of Andros Island have their counterpart in the Great Basin section. Morrison (oral communication, 1954, ) cites occasions when strong winds blowing across the Carson Desert (a huge playa about 20 miles in diameter) drive water from the Carson Sink into areas that normally would be considerable distances from the shore of the lake.

\section{ORIGIN OF STROMATOLITES}

Previous workers have regarded the Cyanophyta and possibly the unicellular Chlorophyta as the organisms responsible for stromatolites. The foregoing discus- sions seem to substantiate this view. However, several important environmental limiting conditions have not been exhaustively explored in considering fossil forms.

The first limiting factor is the depth of water in which the stromatolites developed. Most authors state simply that they developed in shallow water and refer to the maximum penetration of light as the most important factor in controlling the distribution of the Cyanophyta. Cloud (1942, p. 371) reports that the transparency of fresh water is much less than that of the sea water and that stromatolite-building blue-green algae probably do not form large structures below about 10 meters in fresh water and 30 meters in the sea. I am convinced, from my own observations and those of others, that the Cyanophyta are dominant only above low watermark in the marine environment. Modern stromatolites are found only above low watermark. Black's type $A$ grows in the intertidal zone near high watermark. As the tides on Andros Island range from 2.3 feet to 3.0 feet (U. S. Navy, 1951, p. 67), the depth of water over the algal deposits when submerged must be very slight indeed. Here we encounter one of the difficulties in comparing living and fossil stromatolites. Recent stromatolites are quite small, being generally less than a foot in diameter. Many fossil forms are of comparable size or somewhat larger, but a few range up to several feet in diameter and up to 10 feet in height.

Ginsburg (written communication, 1954) seems to think that the difference in scale is not important. His arguments are based primarily upon structural similarity. Cloud, however, (written communication, 1954) feels that during Belt time sea tides of improbably great amplitude (about 10 feet) would have been required to account for such large structures. He prefers the theory that these structures grew below low watermark-on the basis that the blue-green algae have had a long time for habitat variations since the Paleozoic and that perhaps they were forced out of the ocean by competition from better adapted forms. This statement is very possibly true. However, in the light of my observation of algal mats growing on the bottoms of fresh-water lakes, I cannot conceive of a process that would form headlike structures similar to stromatolites other than periodic exposure to subaerial conditions. In all the fresh-water lakes that $I$ have found algal mats, the mats have smooth surfaces that conform to the lake bottoms. Admittedly, the mats will cover irregularities on the bottom, but there is a tendency for the mats to decrease the irregularities rather than intensify them.

A second possible limiting condition involves the salinity of the water in which the stromatolites develop. 
There has been some disagreement over the question of a marine origin vs. a fresh-water origin of these structures. According to Black, the stromatolites of the Bahama Islands range from fresh lake water to water of ocean salinity. The range of salinity is even greater in the continental environments. Here, the environments range from lakes of fresh water, as in central New York, to lakes such as Lake Lahonton, whose salinity has varied greatly with climatic changes and the resultant fluctuations in lake volume during the late Quaternary. It seems safe to state at this time that fossil stromatolites can give us little aid in determining the salinity of ancient lakes.

The third condition is of extreme importance. It concerns the manner in which stromatolites grow. Do they grow by the precipitation of lime from water as a result of photosynthesis, or do the algae develop on the surfaces of unconsolidated, stratified sediments and merely bind the sediments together? Some algae cause the precipitation of lime - either as a loose precipitate or as a hard, stony incrustation around the algal colonies. Several occurrences of this type have been reported in the published record. Probably the best known is the one at Green Lake, N. Y. Here, the form of the deposit is controlled by the growth habit of the algae, and it can be readily seen that a fine precipitate of lime is deposited about the algal filaments. This deposit of finely divided lime adheres to the mucilaginous sheaths of the algae and is gradually built up into a spongy porous mass. Roger Morrison states (oral communication, 1954) that nowhere in the Lahonton region are arborescent algal deposits growing today. Presumably, the highly alkaline composition of the water does not permit the growth of species that develop this form.

The algal mats of Andros Island and the Carson Sink, on the other hand, do not add lime to the sediments. The sediments on $\Lambda$ ndros Island are fine sands and carbonate muds. The algae grow on the surfaces of these sediments; the filaments permeate the sediment as it is deposited and play an important part in binding it. This mode of stromatolite origin has been suggested by Black (1933, p. 167, 186; 1938, p. 166), Young (1935, p. 158), and Cloud and Barnes $(1948$, p. 98,100$)$. Some of the stromatolites of the Belt series are believed to have developed in this manner. Structures such as Collenia frequens Walcott probably did not grow above the surface of deposition as unsupported columns, but developed gradually as the surface was raised due to sedimentation. The columns developed gradually by the periodic increment of algal layers similar to the ones that make up Black's type $B$.

\section{PALEOECOLOGY}

\section{COLLENIA FREQUENS ZONE}

It is possible that this zone was formed under conditions similar to those on Andros Island, where Black's type $B$ occurs. The sediment is a fine-grained dolomitic limestone that is interbedded with edgewise breccia and lenses of dolomitic sandstone or conglomerate. These structures are indicative of frequent disturbance by agitated waters, such as may occur on tidal flats.

Thin sections show an alternation of a fine carbonate mosaic with layers of coarse calcite and dolomite (similar to specimens shown in pl. 24, figs. 5 and 6 ). The grains in the mosaic average about 4 microns in diameter. Conceivably, this fine-grained carbonate was a chemical precipitate mechanically entrapped about the filaments of the algae. The coarsely crystalline calcite and dolomite represent the detrital material that was deposited over the surface of the algal mat during times of high water and considerable agitation.

\section{NEWLANDTA LAMELLOSA WALCOTT}

This form suggests development on mud flats that were alternately wet and dry. Dessication would have caused the edges of the colonies to curl up so as to form bowl-shaped structures. (See pl. 23, fig. 8 ; and fig. 55.) After dessication of the original crusts, new algal mats formed within the bowl-shaped structures, and these were less concave than the original.

\section{COLLENIA UNDOSA ZONES}

Collenia undosa Walcott does not conform to any of the living types described by Black. Wherever this species has been observed, its mineralogical composition differs greatly from the surrounding sediments. The stromatolite invariably occurs as alternating layers of argillite and pure calcite. The enclosing sediment is either argillite or coarse calcareous sandstone. The form of the calcite laminae crudely resembles that of some of the modern encrusting coralline algae.

This species is ordinarily associated with Cryptozoon occidentale Dawson and Collenia symmetrica Fenton and Fenton and is found only in the Collenia undosa zones. The colonies are generally noted to have grown on mud-cracked surfaces. No evidence for desiccation is found after the inception of the colonies, and so it is assumed that they developed upon subsiding surfaces. The presence of coarse limesand and conglomerate, consisting of stromatolite fragments, surrounding the colonies suggests to me that they were subjected to wave action throughout their growth. 


\section{COLLWNIA SYMMETRTCA RONES}

A comparison of figure 54 with figure 5 of plate 22 shows the resemblance between Collenia symmetrioa Fenton and Fenton and Black's type $C$. The one difference between the two forms is that most colonies of Collenia symmetrica do not indicate a period of desiccation after their inception. This species grew upon mud-cracked surfaces which influenced the shape of the laminae in the younger portion of the colonies. Later they formed dome-shaped cross sections. In some of the outcrops, edgewise breccia of stromatolite fragments overlies the biostromes of Collenia symmetrica. (See pl. 22, fig. 5.) The lack of evidence for desiccation after the inception of the colonies and the evidence for strong agitation suggests that this species may have formed upon subsiding mud flats.

\section{CONOPHYTON ZONES}

Conophyton inclinatum $\mathrm{n}$. sp. is the only species that appears to have formed below the zone of agitation. The species is restricted to the two Conophyton zones and seems to have grown under a special set of conditions. No other species of stromatolite is known to occur in the same beds with Conophyton. There is no evidence for desiccation or fragmentation of the colonies by wave action. The surrounding sediments consist of finely laminated limestone that presumably was deposited in a quiet environment. The direction of growth of the colonies is inferred to have been controlled by current action inasmuch as the long axes of the cones lie at low angles to the bedding surfaces.

The colonies themselves are different from other species in the area. They appear to have been attached to the substratum by their conical basal termini. Growth was by the addition of cone-shaped laminae, one upon the other. No forms similar to Conophyton are known to be growing at the present time.

The succession of biostromes in the Conophyton zone 1 indicates a gradual change from a mud-flat environment, on which Collenia frequens Walcott developed, to an offshore or possibly lagoonal environment, in which Conophyton grew, to finally a mud-flat environment, on which Cryptozoon occidentale Dawson and Collenia multiflabella $\mathrm{n}$. sp. were the dominant forms.

In the Conophyton zone 2 the succession is interpreted to represent an alternation of offshore and mudflat environments. Two cycles are indicated by the alternation of biostromes of Conophyton inclinatum n. sp. and Collenia frequens Walcott. (See p. 140.) Subzone $A$ presumably formed as the result of the recession of waters in which the underlying limestones were deposited. On the new mud flats Collenia fre- quens Walcott grew to a thickness of 23 feet. A renewed advance of the shoreline, which caused the mud flats to be permanently submerged, may have fostered growth of colonies of Conophyton inclinatum n. sp. Conditions on the sea bottom then presumably remained the same until a thickness of 35 feet of Conophyton had accumulated.

Some event, perhaps fouling of the water, created conditions that were unfavorable for the growth of Conophyton, and 11 feet of black shaly limestone was deposited. Conophyton may well have been growing in an embayment that received a plentiful supply of well-oxygenated water from the Belt sea. If the embayment were isolated from the sea, the dissolved oxygen near the bottom would have become exhausted and the oxidizing environment would then have given way to a redueing environment in which only anaerobic bacteria could survive. The deposits of such an environment are ordinarily black muds (Hatch, Rastall, and Black, 1938, p. 275). It is likely that subzone $C$ was deposited in such an environment. Filling of the embayment with sediment produced a mud flat and the renewed growth of Collenia frequens Walcott. This condition did not last long, for only about 6 feet of Collenia frequens Walcott (subzone $D$ ) was formed. Another advance of the shoreline brought back the conditions under which subzone $B$ was deposited, and 24 feet of Conophyton beds was deposited to form subzone $E$. The final event was possibly further deepening, which caused the cessation of the growth of Conophyton and the deposition of barren limestone.

\section{COLLENIA MULTIFLABELLA zONE}

This zone represents the continuation of the trend that was begun during the latter part of the Conophyton zone 1. This trend consisted of the beginning of the deposition of argillaceous sediments and probably shallowing of the sea. The amount of argillaceous material increases upward. The boundary between the Siyeh limestone and the Missoula group is placed at the top of this zone. Above lie the argillites of the lower part of the Missoula group.

The dominant species is Collenia multiflabella $\mathbf{n}$. sp. Subordinate amounts of Cryptozoon occidentale Dawson also occur. The basal portions of Collenia multiflabella closely resemble Black's type $B$ and may have formed under somewhat similar conditions. A slight change in the environment, perhaps an influx of finely divided sediment, caused the filling in of the low spots between the algal heads. The new algal mats that grew upon the new surface were large enough to cover several of the older heads. 


\section{CONCLUSIONS}

The use of stromatolite zones for local correlation in the Belt series provides the stratigrapher with an additional tool in an otherwise unfossiliferous sedimentary sequence. Eight zones have been recognized in the Glacier National Park region. The same zones do not appear to extend throughout the outcrop area of the Belt series in northwestern Montana and adjacent States. However, certain zones may extend from a local area into an adjacent one. By using the interfingering zones, new zones in adjacent areas can be correlated in a standard section and the age relations of the Belt series over the entire outcrop belt can be worked out.

In addition to their use as stratigraphic markers, stromatolites may be utilized to distinguish the tops and bottoms of strata. Collenia and Cryptozoon are composed of laminae that are invariably convex upward. In Newlandia the laminae are concave upward, but the genus can be easily distinguished from Collenia on the basis of the arrangement of the laminae. In most occurrences, Conophyton is attached to the substratum by the apex of its conical basal terminus. However, because of the apparently inverted nature of some of the specimens found in the U.S. S. R., caution should be exercised in using this genus in attempts to determine tops of strata.

With the aid of the key, descriptions, and illustrations, the distinctive and stratigraphically significant stromatolites can be recognized. Forms that do not fit the classification may be found. Only those forms that are consistent in their characteristics over wide areas have been described here. In some places an algal limestone may be suspected without identification of any distinctive structures. As has been pointed out, algal deposits may vary from mere intensification of regular sedimentary lamination to such complex structures as Collenia multiflabella $\mathrm{n}$. sp.

Many stromatolites of the Belt series closely resemble certain structures that are forming at the present time. Until the environmental factors to which these structures are related are better understood, it would be inadvisable to attempt exact correlations between fossil and modern environments. As previously observed, the range in salinity of the water in which these organisms grow is extreme. My own limited survey of the published record and of modern environments suggests that the dominant forms in marine or salt-lake environments are stromatolitelike structures, whereas in the freshwater lakes and streams the dominant structures are arborescent masses or unattached spheroidal concretionary masses. Just how far this tentative generalization can be extended remains to be seen.

\section{SELECTED BIBLIOGRAPHY}

Almeida, F. M. de, 1944, Collenia itapevensis, sp. nov., um fóssil pré Cambriano do Estado de São Paulo: São Paulo Univ. Bol., Faculdade de.Filosofia, Ciências e letras, no. 45 (geol. no. 1), p. 89-106, pls. 1-4.

Ashley, B. E., 1937, Fossil algae from the Kundelungu series of Northern Rhodesia: Jour. Geology, v. 45, no. 3, p. 332335, fig. 1.

Bauerman, Hilary, 1885, Report on the geology of the country near the forty-ninth parallel of north latitude west of the Rocky Mountains, from observations made in 1859-61: Canada Geol. Survey, Rept. Progress 1882-84, B.

Black, Maurice, 1933, The algal sediments of Andros Island, Bahamas: Royal Soc. London Philos. Trans., ser. B, v. 122, p. 165-192, figs. 1-16, pls. 21, 22.

Bradley, W. H., 1929, Algae reefs and oolites of the Green River formation: U. S. Geol. Survey Prof. Paper 154, p. 203-224, pls. 28-48.

Guhen, Lucien, Jamotte, A., and Mortelmans, G., 1946, Note preliminaire sur les Algues des series Calcaires Anciennes du Congo Belge: Service geol. Congo Belge et Ruando-Urandi Bull. 2, fasc. 2, p. 171-236, figs. 1-23, Léopoldville, Belgian Congo.

Ohoubert, Georges, 1945, Sur la découverte de Collenia dans le Pré Cambrian de l'Atlas Oriental: Soc. Géol. de France Compte rendus sommaire, p. 182-184.

____ 1952, Contribution à l'etude du Cambrian Inférior et du Pré Cambrian III de L'Anti-Atlas Marocain Par. Pierre Hupé: Morocco Service des Mines et de la Carte Géol., Notes et Mem. no. 103, p. 297-333, figs. 72-99, pls, 12-24, Rabat, French Morocco.

Chonbert, Georges, du Dresnay, R., et Hindermeyer, J., 1950, Sur les calcaires a Collenia de la région Safsaf-Äin Chaïr : Morocco Service des Mines et de la carte Géol. Notes et Mem. no. 76 , p. 93-103, pis. 1-5, figs. 1-6, Rabat, French Morocco.

Glapp, C. H., 1932, Geology of a portion of the Rocky Mountains of northwestern Montana: Mont. Bur. Mines and Geology Mem. 4, p. 1-30, pl. 1 .

('arke, J. M., 1900, The water biscuit of Squaw Island, Canandaigua Lake, N. Y.: N. Y. State Mus. Bull,, v. 39, p. 195198, pls. 12-15.

Clond, P. E., Jr., 1942, Notes on stromatolites: Am. Jour. Sci., v. 240 , p. 363-379, fig. 1 , pls. 1 and 2.

- 1952, Facies relationships of organic reefs: $\Delta \mathbf{m}$. Assoc. Petroleum Geologists Bull., จ. 36, no. 11, p. 2125-2149, figs. 1-4.

Clond, P. E., Ir., and Barnes, V. E., 1948, The Ellenburger group of central Texas: Texas Univ., Bur. Econ. Geology Pub. 4621 ; p. 1-473, figs. 1-8, pls. 1-45.

Daly, R. A., 1912, Geology of the North American Gordillera at the forty-ninth parallel: Canada Geol. Survey Mem. 38.

Dawson, J. W., 1897, Note on Cryptozoon and other ancient fossils : Ganadian Rec. Sci., v. 7, p. 203-219.

Dorn, Paul, 1953, Die Stromatolithen des Unteren Bundsandsteins in Nördlichen Harzvorland: Neues Jahrb. fuir Geol. und Paläont., Abh. 97 (1/3), p. 20-38.

Endo, Riuji, and Resser, C. E., 1937, The Sinian and Cambrian formations and fossils of southern Manchoukuo: Manchurian Scl. Mus. Bull. I, Mukden. Educ. Inst., Southern Manchuria Ry. Co., 474 p., pls. 1-73, 
Fairbridge, R. W., 1950, Pre-Cambrian algal limestone in western Australia: Geol. Mag., y. 87, no. 5, p. 324-330, flgs. 1 and 2 , London.

Fenton, O. L., 1943, Pre-Cambrian and Early Paleozolc algae: Am. Midland Naturalist, v. 30, p. 83-112.

Fenton, C. L., and Fenton, M. A., 1981, Algae and algal beds in the Belt series of Glacier National Park: Jour. Geology, v. 39 , p. $670-686$, fig. 1 , pls. $1-9$.

- 1933a, Oboloid brachiopods in the Belt series of Montana [abs.] : Geol. Soc. America Bull., v. 44, p. 190.

1933b, Algal reefs or bioherms in the Belt series of Montana: Geol. Soc. America Bull., v. 44, p. 1135-1142, pl. 57, figs. 1 and 2.

___ 1936, Walcott's "Pre-Cambrian Algonkian algal flora" and associated animals: Geol. Soc. America Bull., v. 47, no. 4, p. 609-620, pls. 1-3, fig. 1 .

—_ 1987, Belt series of the north : Stratigraphy; sedimentation, paleontology : Geol. Soc. America Bull,, v. 48, p. 18731970, pls. 1-19, figs. 1-20.

Ginsburg, R. N., 1955, Recent stromatolitic sediments from south Florida [abs.] : Jour. Paleontology, v. 29, p. 723.

Goldring, Winifred, 1987, Cryptozoon: Plant nature and distribution: Science, v. 86, no. 2241, p. 530.

Gurich, G., 1906, Les Spongiostromides du Viseen de la province de Namur: Mus. royal d'Histoire naturelle de Belgique Mem. 3 (4), p. 1-55, pls. 1-23.

Hall, James, 1883, Cryptozoon (proliferum) N. G. (and sp.) : N. Y. State Mus. Ann. Rept. 36, pl. 6 and expl.

Hatch, F. H., Rastall, R. H., and Black, Maurice, 1938, The petrology of sedimentary rocks, p. 1-383, figs. 1-75, London, George Allen and Unwin Ltd.

Høeg, O. A, 1929, Studies in stromatolites I: A postglacial marine stromatolite from southeastern Norway: Norske Videnskabers Selskabs, Skrifter, 1929 , no. 1, p. 1-60, figs. 1-18, pls. 1-8.

Holtendahl, Olaf, 1918, Bidrag til Finmarkers Geologi : Norges Geologiske Unders $\not k e l s e$, no. 84, p. VII-314, pls. 1-21, 2 geol. maps, English summary p. 297-314.

- 1921, On the occurrence of structures like Walcott's Algonkian algae in the Permian of England: Am. Jour. Sci., I, ser. V, p. 195-206.

Howe, M. A., 1918, in Britton, N. L., Flora of Bermuda: Algae, p. 489-550.

1932, The geologic importance of lime-secreting algae: U. S. Geol. Survey Prof. Paper 170-E, p. 57-64, pls. 19-23.

Jamotte, A., 1944a, Note sur la probabilité de l'existence d'Alques fossiles du genre Collenia dans la série des mines du Katanga : Mai 1941, Pub. Comité spécial du Katanga, Elisabethville, p. $6-8$.

- $1944 \mathrm{~b}$, Nouvelles observations sur la présence d'organismes du genre Oollenia dans la série des Mines: Octobre 1941, Pub. Comité spécial du Katanga, Elisabethville, p. 9-12.

Johnson, J. H., 1946, Lime-secreting algae from the Pennsylvanian and Permian of Kansas: Geol. Soc. America Bull., v. 57, p. 1087-1120, pls. 1-10.

- 1952, Ordovician rock-building algae: Colo. School Mines Quart., v. 47, no. 2, p. 1-56, pls. 1-12.

Jones, I. C., 1925, The geologic history of Lake Lahonton: Carnegie Inst. Washington Pub. 352, p. 1-50, figs. 1-22.

Kalkowski, Ernst, 1908, Oolith und stromatolith in Norddeutchen Bund-sandstein : Deutsche geol. Gesell. Zeitschr., Band 60, p. 68-125, figs. 1-3, pls. 4-11.
Lanjouw, J., 1952, International code of botanical nomenclature: The Chronica Botanica Co., Waltham, Mass., p. 1-228.

MacGregor, A. M., 1940, A pre-Cambrian algal limestone in Southern Rhodesia: Geol. Soc. South Africa Trans., v. 43, p. 9-16, figs. 1 and 2, pls. 2-5.

Maslov, V. P., 1937a, On the Paleozolc rock-building algae of east Siberia: Moscow Univ. Lab. Paleontology Pub., Problems of paleontology, v. 2 and 3, p. 249-325, figs. 1-16, pls. 1-12, English summary, p. 314-325.

- 1937b, On the distribution of calcareous algae in east Siberia: Moscow Univ. Lab. Paleontology Pab., Problems of paleontology. v. 2 and 3, p. 327-342, figs. 1-6, pls. 1-5, English summary, p. 342-348.

1938, On the nature of the stromatolite Conophyton: Moscow Univ. Lab. Paleontology Pub., Problems of Paleontology, v. 4, p. 325-329, pl. 1. English summary, p. 329-332.

- 1939a, The genus Collenia: Moscow Univ. Lab. Paleontology Pub., Problems of paleontology, v. 5, p. 297-310, figs. $1-4$, pls. 1-4.

- $1939 \mathrm{~b}$, An attempt of the age determination of unfossillferous beds in the Urals with the ald of stromatolites: Moscow Univ. Lab. Paleontology Pub., Problems of paleontology, v. 5, p. 277-281, fig. 1, pls. 1 and 2, English translation, p. 281-284.

Mawson, Sir Douglas, 1925, Evidence and indications of algal contributions in the Cambrian and pre-Cambrian limestones of South Australia: Royal Soc. South Australia Trans., v. XLIX, p. 186-190, pls. XIII-XV.

1929, Some South Australian algal limestones in process of formation: Geol. Soc. London Quart. Jour., v. 85, pt. 4 , p. 613-623, pls. 35-41.

Menchikoff, Nicolas, 1946, Les formations a Stromatolithes dans le Sahara Occidental: Soc. Géol. de France Bull. 16, p. 451-461.

Meyer, A., 1954, Une formation a Collenia dans la région de Niangara (Uele, Congo belge) : Soc. Belge géol., palaeont. et hydrologie Bull., tome 62, fasc. 2 and 3 , p. 213-216, fig. 1 .

Pia, Julius, 1927, Die Erhaltung der fossilen Pflanzen, Abt. 1, Thallophyta, in Hirmer, M., 1927, Handb: der Palaobotanik, p. 1-136: Munchen und Berlin 1.

1933, Die Rezenten Kalksteine: Zeitschr. für Kristallographie, Mineralogie, und Petrographie Abt. B., p. 1-420, figs, $1-22$, pls. $1-4$.

Rao, M. R. Srinivasa, 1949, Algal structures from the Cuddapah limestones (pre-Cambrian), South India: Mysore Univ. Half-yearly Jour., sec. B/9 (2), p. 67-72.

Rezak, Richard, 1953, Algal zones in the Belt series in the Glacier National Park region, Montana [abs.] Geol, Soc. America Bull., v. 64, p. 1553.

Riedel, Alfred, 1953, Remarques sur la systématique et la valeur stratigraphique de quelques stromatolithes du Moyen-Congo: Soc. Géol. de France Bull. $6^{\circ}$ série, tome $3^{\circ}$, fasc. $7-8$, p. $667-675$.

Roddy, H. J., 1915, Concretions in streams formed by the agency of blue-green algae and related plants: Am. Philos. Soc. Proc., v. 54, p. 246-258, figs. 1-2.

Russell, J. C., 1885, Geologic history of Lake Lahonton: U. S. Geol. Survey Mon. v. XI, p. 1-288, figs. 1-35, pls. 1-46.

Rutherford, R. L., 1929, Pre-Cambrian algal structures from the Northwest Territories, Canada: Am. Jour. Scl., v. 17, p. 258-259, flg. 1.

Schnock, P., 1947, Sur les Algues Calcares deconvertes dans le Sud-Est de la Cuvette Central du Congo Belge: Acad. Sci. Paris Compte rendu 224, no. 19, p. 1369-1371, May 12, 1947. 
Schwellnus, C. M., and le Roex, H. D., 1945, Columnar, conical, and other growths in the dolomites of the Otavi System, S. W. A. [South-West Africa]: Geol. Soc. South Africa Trans, v. 47 , p. 93-104, figs. 1-6, pls. 16-19.

Seely, H. M., 1906, Cryptozoa of the early Champlain sea: Rept. of Vermont State geologist, 1905-06, p. 156-173, pls. 34-38.

Taylor, W. R., 1928, The Marine algae of Florida with special reference to the Dry Tortugas: Papers from the Tortugas Lab., Carnegie Inst. Washington, v. 25, no. 379, p. 1-219, pls. 1-37.

Teilhard de Chardin, Pierre, 1952, Sur la nature et la signification des Collenia pré cambriennes: Acad. Sci. Paris Compte rendu 235 , no. 16 , p. 845-847.

Twenhofel, W. H., 1919, Pre-Cambrian and Carboniferous algal deposits : Am. Jour. Sci,, v, 48, p. 343-346.

Tyler, S. A., and Barghoorn, E. S., 1954, Occurrence of structurally preserved plants in pre-Cambrian rocks of the Canadian Shield: Science, v. 119, no. 3096, p. 606-608.

U. S. Navy, 1951, Sailing directions for the West Indies : Hydrographic Office Pub. no. 128, p. 1-432.

Vasconcelos, P., 1951, Sur la docouverte d'algues fossiles dans les terraines anciens de l'Angola: Internat. Geol. Cong. Rept. of 18th Sess., pt. XIV, pp. 288-293, fig. 1.

Walcott, C. D., 1899, Pre-Cambrian fossiliferous formations: Geol. Soc. America Bull., v. 10, p. 199-244, pls. 22-28. 1906, Algonkian formations of northwestern Montana: Geol. Soc. America Bull., v. 17, p. 1-28, pls. 1-11.
Walcott, C. D., 1910, Abrupt appearance of the Cambrian fauna on the North American Continent: Smithsonian Misc. Coll., v. 57, no. 1, pub. 1940, p. 1-16.

1914, Pre-Cambrian Algonkian algal flora: Smithsonian Misc. Coll., v. 64, no. 2, p. 77-156, pls. 4-23.

Woodring, W. P., 1954, Conference on biochemistry, paleoecology, and evolution: Natl. Acad. Sci. Proc., v. 40, no. 3, p. 219-224.

Young, R. B., 1933, The occurrence of stromatolites or algal limestones in the Campbell Rand series, Griqualand West: Geol. Soc. South Africa Trans., v. 35, p. 29-36, fig. 1, pls. 4-6.

1935, A comparison of certain stromatolitic rocks in the Dolomite series of South Africa with marine algal sediments in the Bahamas: Geol. Soc. South Africa Trans., v. 37 , p. 153-162, pls. 3-6.

1940, Further notes on algal structures in the Dolomite series: Geol. Soc. South Africa Trans., v. 43, p. 17-21, fig. 1 , pls. 6-8.

1943, The domical-columnar structure and other minor deformations in the Dolomite series: Geol. Soc. South Africa Trans., v. 46, p. 91-106.

1945, Nodular bodies in the Dolomite series: Geol. Soc. South Africa Trans., v. 48, p. 43-48, pls. 4-6.

Young, R. B., and Mendelssohn E., 1942, Domed algal growths in the Dolomite series of South Africa, with associated fossil remains: Geol. Soc. South Africa Trans., v. 51, p. 58-62, figs. 1-3, pls. 7-15. 
: 


\section{INDEX}

[Italic numbers indicate description]

Page

Abstract.

Acknowledgments

albertensis, Collenia

Aldan river, U. S. S. R., stromatolite oceurrence..... 135

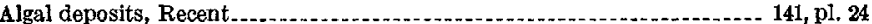

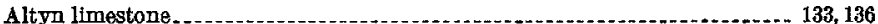

Andros Island, types of modern algal deposits .

Bibligraphy

Big Belt Mountains, stromatolite occurrence

Black, Maurice, cited.

quoted.

142

Bodensee [Lake Constance], Bavaria, types of algal deposits ................... 144

Bradley, W. H., quoted................ 144

Burke formation.

Callothrix

Canandaigua Lake, N. Y., occurrence of water blscuits

Carson Stnk, Nev., occurrence of Recent algal deposits.

Chlorophycere

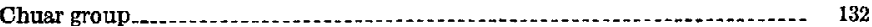

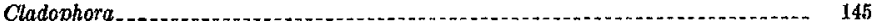

clappii, Collenia

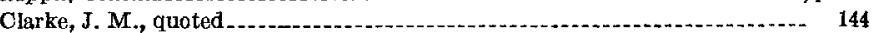

Classiffertion of stromatolites, opinions concerning

present.

previous

$129-130$
$-\quad 131$

$130-131$

Clond, P. E., Jr., cited

Cloud, P. E., Jr., and Barnes, V. E., cited............................... 147

Coeur d'Alene district, Idaho, stromatolite occurrence................... 128, 131

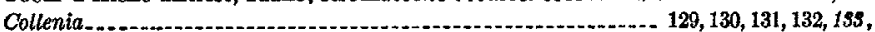
$134,136,137,138,139,140,147,148,149$, pls. 19, 20, 21, 22, 24

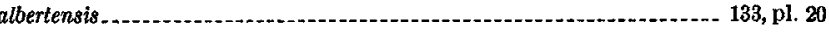
clappii columnaris

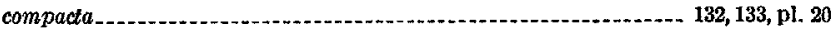

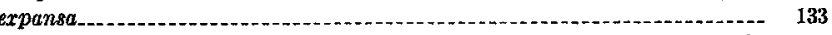
frequens.................... 127, 130, 13s, 135, 136, 138, 139, 140, 147, 148, pls. 19, 20 multiflabella................. 131, 132, 133, 134, 136, 137, 138, 148, 149, pls, 19, 21, 22

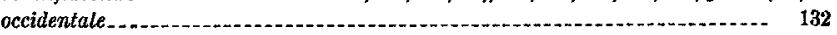
parva.

132, 1S4, 136, 137, 139, 147, 148, pls, 19,22 undosa. . .

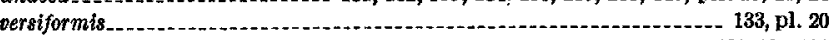
villisii

sp.................... pl. 24

Collenia frequens zone-136, 147

multiflabella zone......................................................... 138, 148

symmetrica zone 1 ............. 137, 148

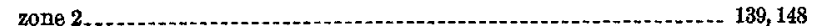

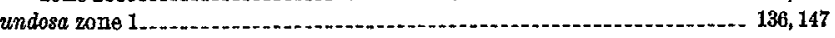

zone 2 139, 147

Colony, form of 131 size of. .................... 132

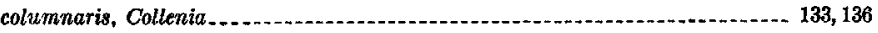

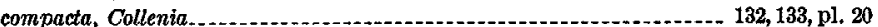

concentrica, Newlandia...................................................... 131

Conophyton........................... 131, 134, 1s5, 138, 140, 148, 149, pls, 18, 19, 23 inclinatum.................................... 132, 195, 138, 140, 148, pls, 19, 23

lituus_................... 135

Conophyton zone 1 .

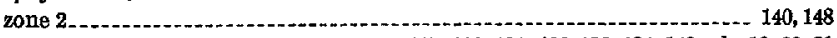

Cryptozoon .............................. 127, 131, 132, 133, 134. 149, pls. 19, 20, 21 occidentale $\ldots . . . . . .130,131,192,133,136,138,139,147,148$, pls. 19, 20, 21 proliferum.

141, 132
Page

Dolomite serles, Transvaal, stromatolite occurrence......................... 135

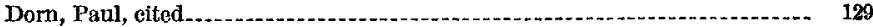

Dry Tortugas, marine algae oceurrence

expansa, Collenia

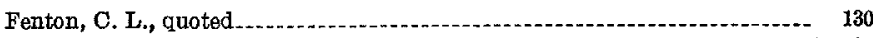

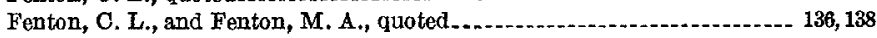

Florlda, occurrence of modern algal deposits................................ 142, 144

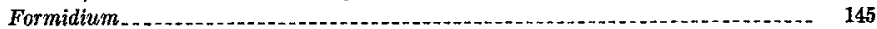

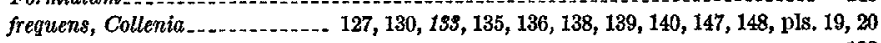

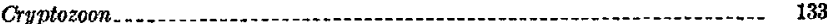

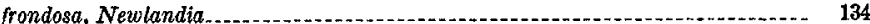

Furnace Creek, W. Va., occurrence of laminated calcareous pebbles._... 144

Genera, present basis of distinction.

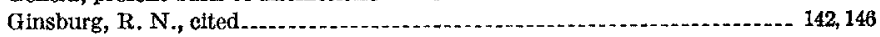

Grand Crnyon, Ariz., stromatolite occurrence............................. 132

Green Lake, N. Y., modem spongiostromes................................ 147

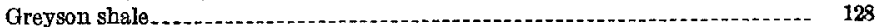

Grinnéll argillite........................ 132, 133, 134, 136

Growth, mode of, basis of generic distinction.................................. 131

Hæll, Jimes, quoted .

Helena limestone.

Helena, Mont., stromatolite occurrence........................................ 128

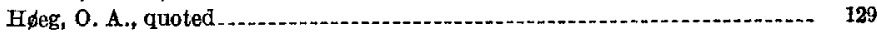

Howe, M. A., quoted............... 141, 144

inclinatum, Conophyton

Jobnson, J. H, quoted_._.

Kalkowskl, Ernst, eited .

Key to identification of stromatolites.......................................... 132

Lahonton, Lake, types of tufa . . . . . . . lameliosa, Newlandia

Laminae, nature of

Libby, Mont., stromatolite occurrence-........ 128

Little Belt Mountains, stromatolite occurrence.............. 128

Little Birch Creek, Mont., stromatolite occurrence......................... 134

Little Conestoga Creek, Pa., occurrence of calcareous concretions............ 144

lituus, Conophyton.

Mala river region, U. S. S. R., stromatolite occurrence

Maslov, V. P. cited......... 130, 135

Meagher County, Mont., stromatolite occurrence............ 133

Missoula group

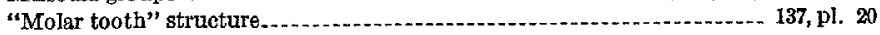

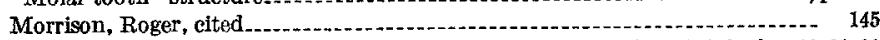

multiflabella, Collenia _..._._... 131, 132, 133, 184, 136, 137, 138, 148, 149, pls. 19, 21, 22

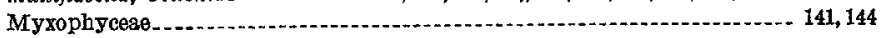

Namur Basin, Belgium, occurrence of laminated structures in limestone-...-. 129

Newland limestone

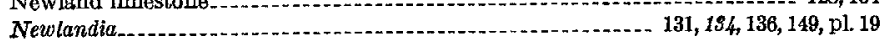
concentrica................. 131

frondosa $a_{-}$

lamellosa............................... 194, 147, pls. 19

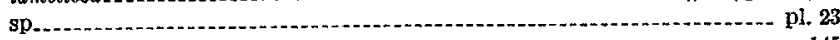

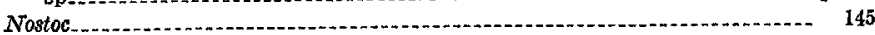

occidentale, Collenia

Cryptozoon Oncolithi. 


\begin{tabular}{|c|c|}
\hline Page & Page \\
\hline Origin of stromatolites. & Squaw lstand, Canandaigua Lake, N. Y., occurrence of water biscuits....-.-. \\
\hline Osagia & Striped Peak formation. \\
\hline Otavi Mountains, South Africa, stromatolite occurrence. & symmetrica, Collenia \\
\hline Ottonosia & (n) \\
\hline 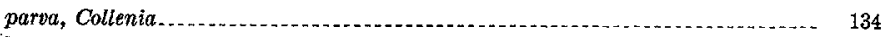 & Troy, Mont., stromatolite occurrence. \\
\hline Pia, Julius, eited & Tufa......................... \\
\hline roup.......-n & dendritic....... \\
\hline ation & 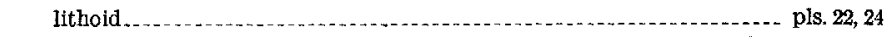 \\
\hline proliferum, Cryptozoon & Types, explanation of abbreviations of museums and collections used in descrip- \\
\hline Pycnostroma & tions...... \\
\hline Pyramid Lake, Nev., oecurrence of modern tufas....... 145 & \\
\hline Ravalli group........... & 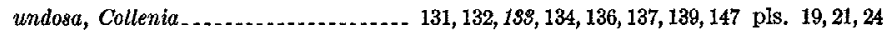 \\
\hline Riedel, Alfred, cited & vérsiformis, Collenia. \\
\hline Roddy, H. J., cited & \\
\hline 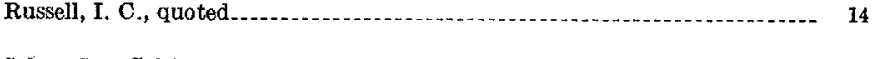 & $\begin{array}{l}\text { Walcott, C. D., cited. } \\
\quad \text { quoted. }\end{array}$ \\
\hline f., occurrence of tufas ..... & 128 \\
\hline Seely, H. M., quoted. & White Sulphur Springs, Mont., stromatolite occurrence................... 133, 134 \\
\hline Siyeh limestone.......... 132,133,134, 135, 137, 148 & willisii, Collenia \\
\hline ev., occurrence of lithoid tufas. & \\
\hline Species, characteristics of & Toung, R. B., eited. \\
\hline e stale & quoted..... \\
\hline Spongiostroma & \\
\hline Spongiostromes, outline of environments....... 145-146 & \\
\hline
\end{tabular}




\section{PLATES 19-24}




\section{PLATE 19}

The following figures accompany the key to the identification of stromatolites.

Frgure 1. Cryptozoon occidentale Dawson

2. Collenia undosa Walcott

3. Collenia symmetrica Fenton and Fenton

4. Collenia multiflabella n. sp.

5. Collenia frequens Walcott

6. Newlandia lamellosa Walcott

7. Canophyton inclinatum $\mathrm{n}$. $\mathrm{sp}$.

\section{KEY TO THE IDENTIFICATION OF STROMATOLITES IN THE BELT SERIES}

[Figures are giren on plate 19]

I. Incrusting forms, growth upwards from a point on the substratum by the addition of convex upward laminae

A. Gross form turbinate.

Genus: Cryptozoon

1. Laminae conform to upper surface of colony in later stages of development.

a. Laminae smooth .... II. Incrusting forms, growth upwards from a surface on the substratum by the addition of convex upward laminae

Genus: Collenia

A. Gross form hemispheroidal or depressed spheroidal.

1. Laminae conform to upper surface of colony.

a. Laminae coarsely crenulate Collenia undosa, figure 2

b. Laminae smooth

2. Laminae conform to upper surface of colony only during later stages of development.

a. Laminae finely crenulate. ...

B. Gross form irregularly cylindroidal.

1. Laminae flattened to strongly convex.

a. Laminae smooth

III. Incrusting forms, growth upwards from a surface on the substratum by the addition of concave upward laminae

Genus: Newlandia

A. Gross form hemispheroidal.

1. Laminae do not conform to outer surface of colony.

a. Laminae smooth . .

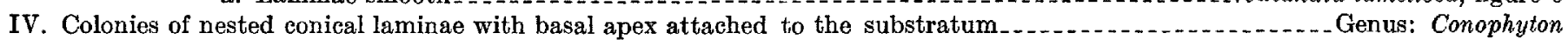
A. Gross form cylindroidal.

1. Axes of cylindroids at a low angle to bedding.

a. Laminae smooth. 


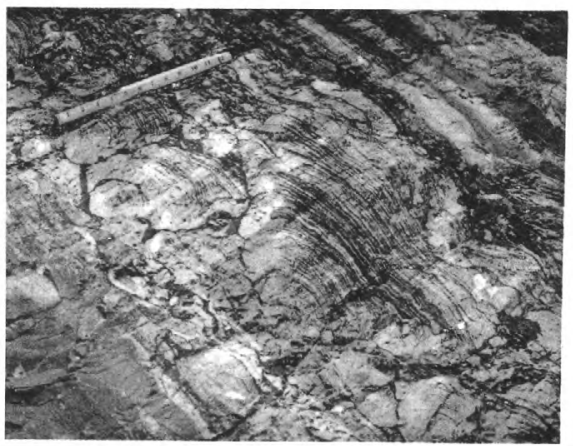

1

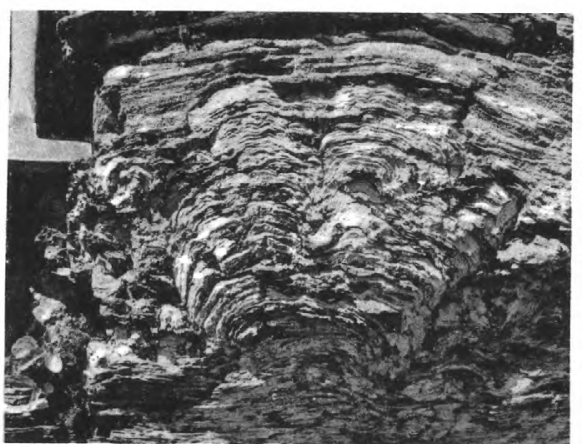

2

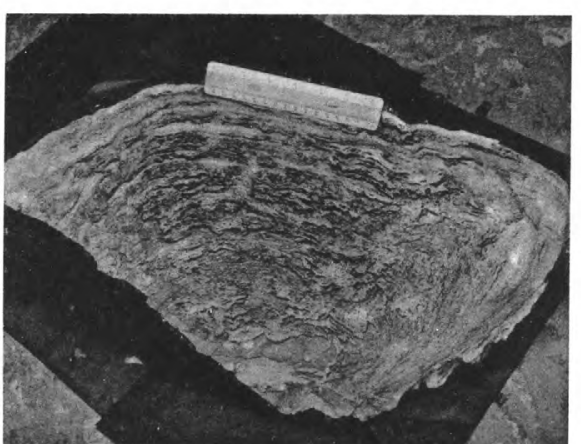

3

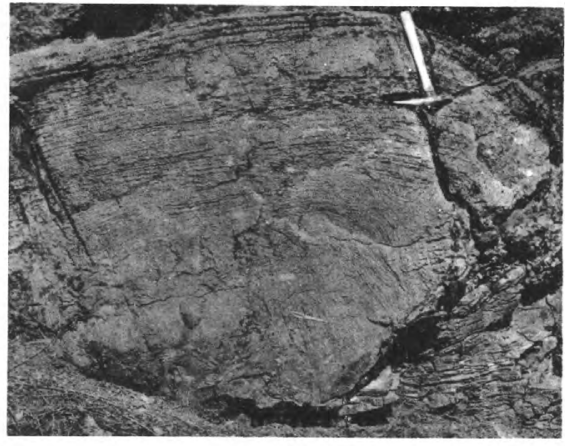

4

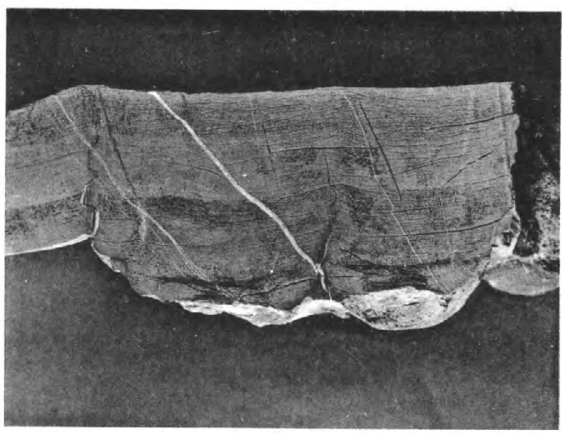

6

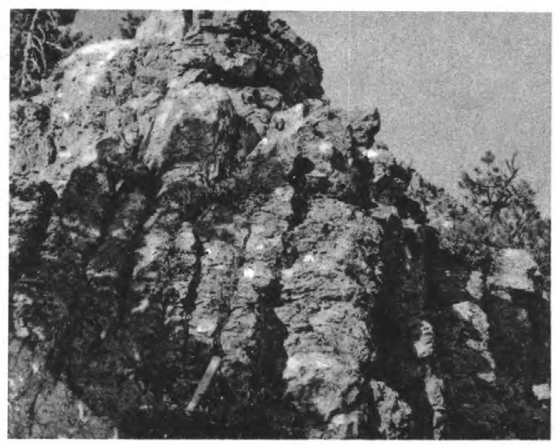

5

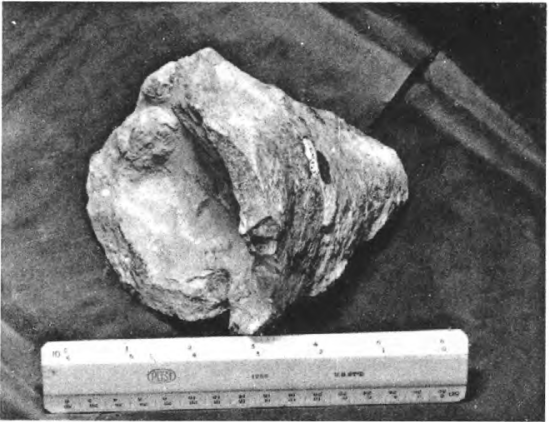

7

SPECIMENS SHOWING CHARACTERISTIC STRUCTURES USED IN KEY TO IDENTIFICATION

OF STROMATOLITES 


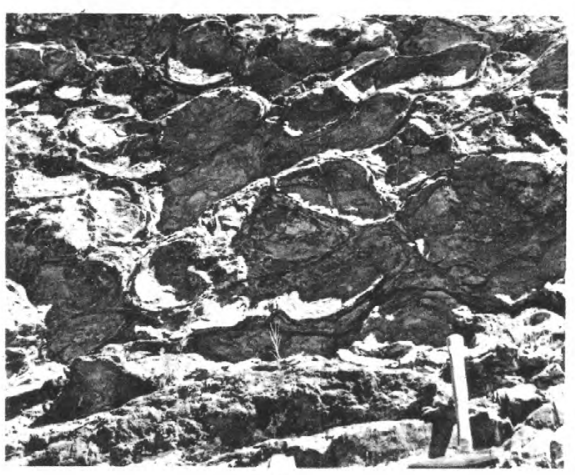

1

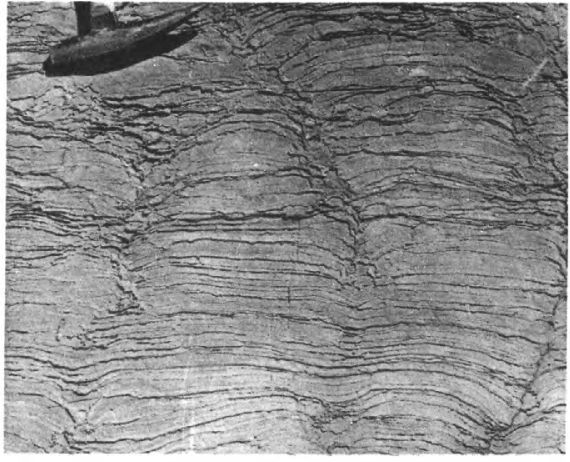

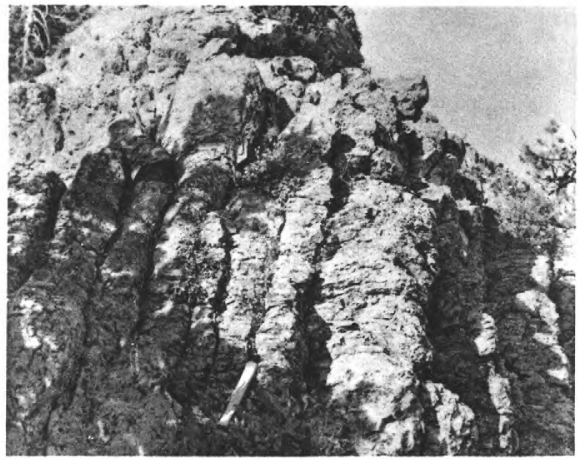
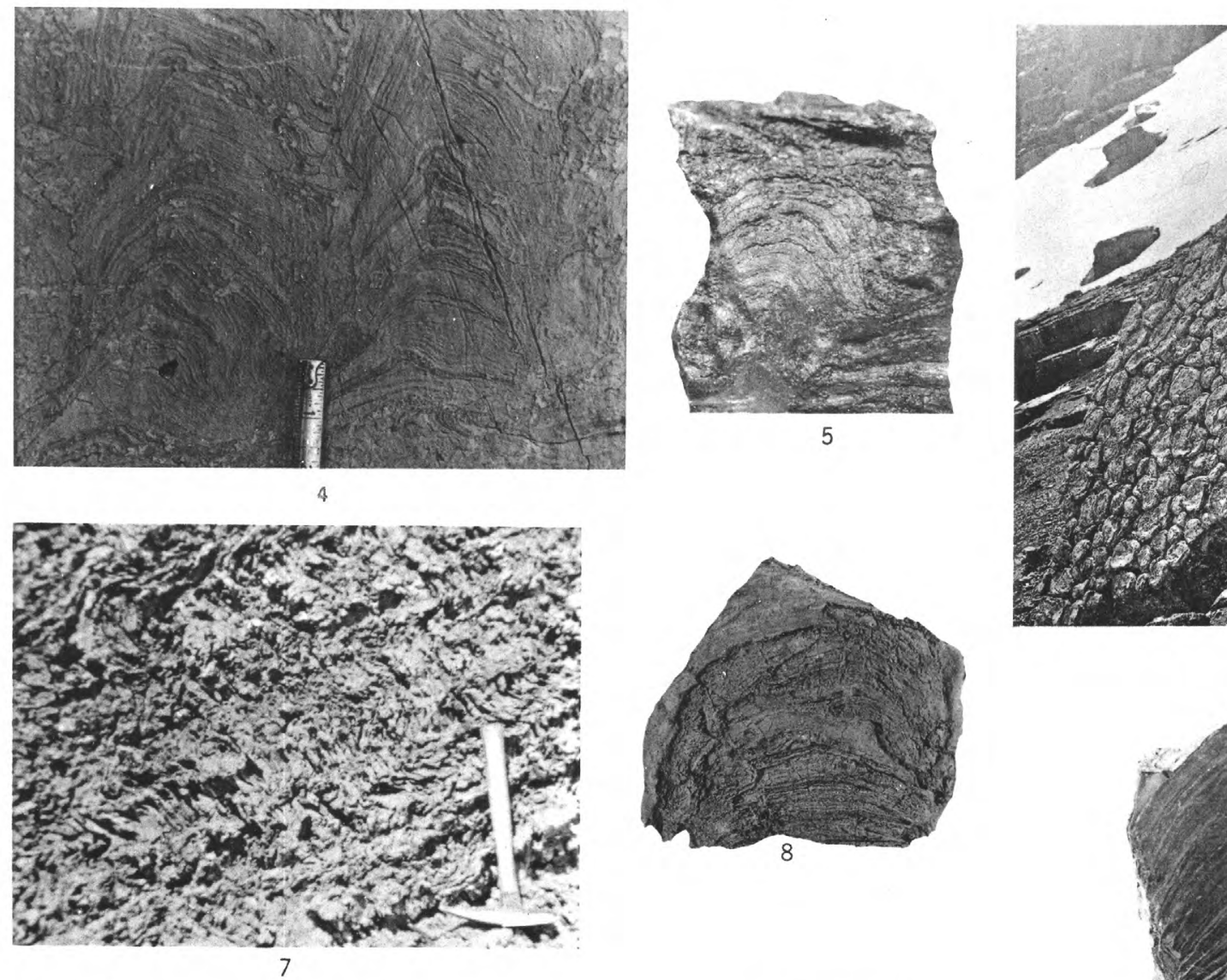

3

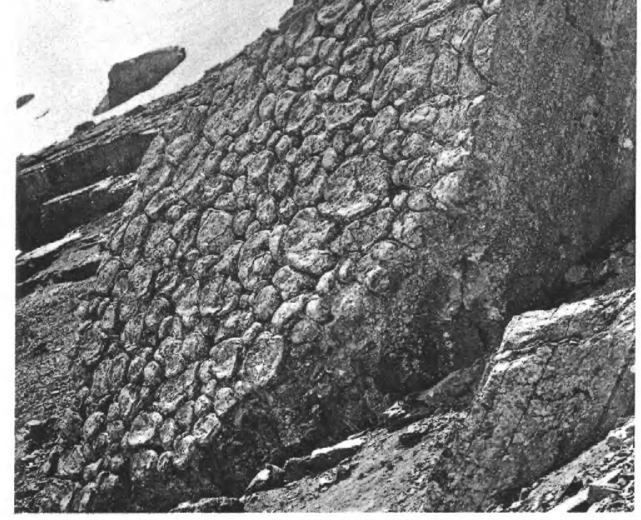

6
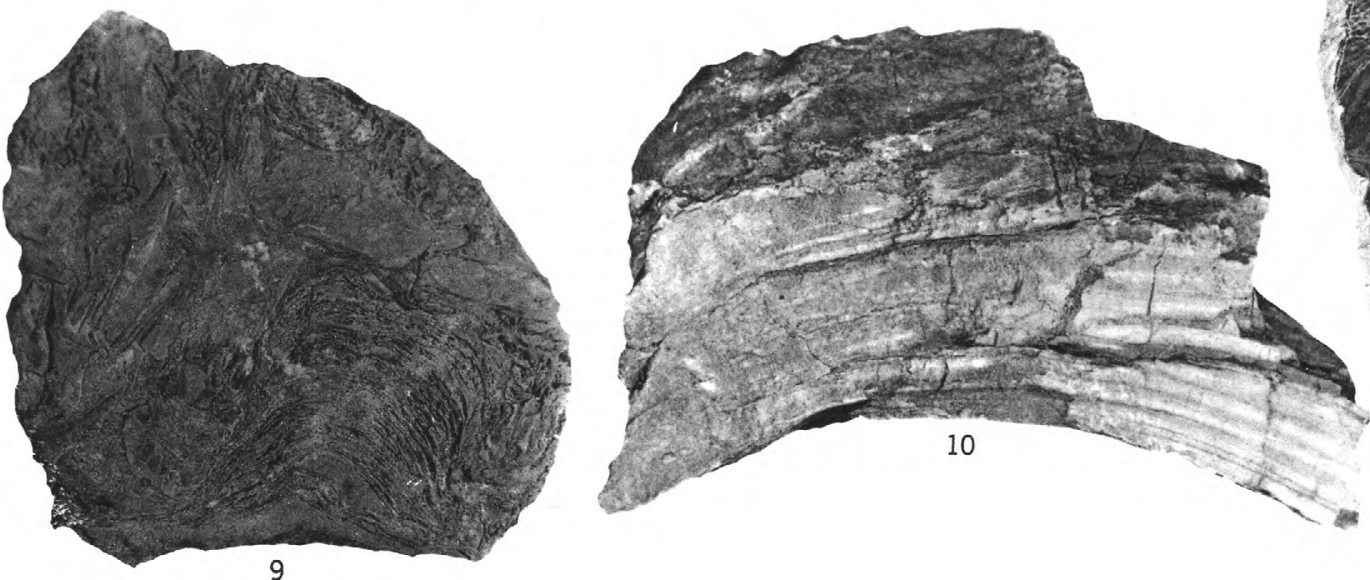

9

COLLENIA FREQUENS, CRYPTOZOON OCCIDENTALE, AND THE "MOLAR TOOTH" STRUCTURE 


\section{PLATE 20}

Figurs 1. Collenia frequens Walcott in Conophyton zone 2 (p. 133).

The underside of a biostrome of $C$. frequens, showing a basal view of the cylindroidal colonies. North wall, valley of the Middle Fork Flathead River, opposite mouth of Cy Creek.

2. Collenia frequens Walcott in Conophyion zone 1 (p. 133).

Closeup of a joint surface showing longitudinal section of cylindroids with very gently convex laminae. On trail about 1/2 miles north of Fifty Mountain Camp.

3. Collenia frequens Walcott in Conophyton zone 2 (p. 133).

Joint surface showing cylindroidal nature of colonies. Type site of Conophyton zone 2 at top of Running Rabbit Mountain.

4. Collenia frequens Walcott $\left(\times \frac{1}{2}\right)$, in Collenia frequens zone (p. 133).

Closeup of a joint surface showing longitudinal section of cylindroids with strongly convex laminae. On trail just east of Appekunny Falls.

5. Cryptozoon occidentale Dawson ( $\times 1 / 2)$, Siyeh limestone (p. 132).

Holotype of Collenia compacta Walcott. From Continental Divide at head of Kipp Creek. USNM 60712.

6. Collenia frequens Walcott, Siyeh limestone (p. 133).

This photograph, taken by Bailey Willis in 1901, is the only material on which Walcott based his description of the species. The following notes accompany the photograph: "Photo No. 325, Rock mass showing large concretionary or coralline masses in the Siyeh formation about 500 feet from top of the formation. Head of McDonald Creek. Ridge between McDonald and Logging Creeks near the summit, Montana. August 7, 1901."

7. "Molar tooth" structure, Siyeh limestone (p. 137).

The Garden Wall trail near Logan Pass.

8. Collenia frequens Walcott $(\times 1 / 2)$ (p. 133).

Holotype of Collenia albertensis Fenton and Fenton. From the Altyn limestone on the north slope of Gable Mountain. PUM 24021.

9. Collenia frequens Walcott $(\times 1 / 2)$ (p. 133).

Holotype of Collenia versiformis Fenton and Fenton. Note the similarity to specimen in plate 20, figure 8 . PUM 24027.

10. Collenia frequens Walcott $(\times 1)$ (p. 133).

Part of colony showing fragmentary nature of collected specimens. Conopyton zone 2, in railroad-cut along Bear Creek opposite mouth of Devil Creek. USGS a117.

11. Collenia frequens Walcott $(\times 1 / 2)$ (p. 133).

Polished longitudinal section of cylindroid. Conophyton zone 2, on north side of trail about 4 miles up Ole Creek trail. USGS a249. 


\section{PLATE 21}

Figure 1. Cryptozoon occidentale Dawson, Missoula group (p. 132).

Biostrome developed on surface of lenticular coarse sandstone. Upper surface of biostrome overlain by breccia composed of stromatolite fragments. Railroad-cut about 3 miles southeast of Nyack, Mont.

2, 3. Cryptozoon occidentale Dawson (X 1/2), Chuar group (p. 132).

Grand Canyon, Ariz. Walcott, in 1916, called these Collenia occidentale (Dawson). Owing to the present distinction between the two genera, it is necessary to refer these specimens to the genus Cryptozoon. USNM 60711 and 60710 .

4. Collenia undosa Walcott $(X / 2)$ (p. 133).

This specimen, labeled the holotype of Collenia willisii Fenton and Fenton, does not appear to be the specimen figured by them (1937) as figure 1 of plate 11. PUM 24020.

5. Collenia undosa Walcott, Missoula group (p, 133).

Joint surface shows typical development of biostromes of $C$. undosa. Overlying rock is argillite. South of Walton, Mont., 1.2 miles, on U. S. Highway 2.

6. Collenia multiflabella n, sp. ( 1 1/2), from Collenia multiflabella zone at Logan Pass (p. 134).

Holotype. USGS a118.

7. Collenia undosa Walcott, in Collenia undosa zone 2 (p. 133).

Upper surface of a biostrome, showing mammilate nature of colonies. Cirque between Clements Mountain and Mount Oberlin.

8. Collenia undosa Walcott, in Collenia undosa zone 2 (p. 133).

Colony underlain by finely laminated argillite; overlain by coarse calcareous sandstone. Stromatolite made up of alternating layers of pure limestone and argillite. Cirque between Clements Mountain and Mount Oberlin. 


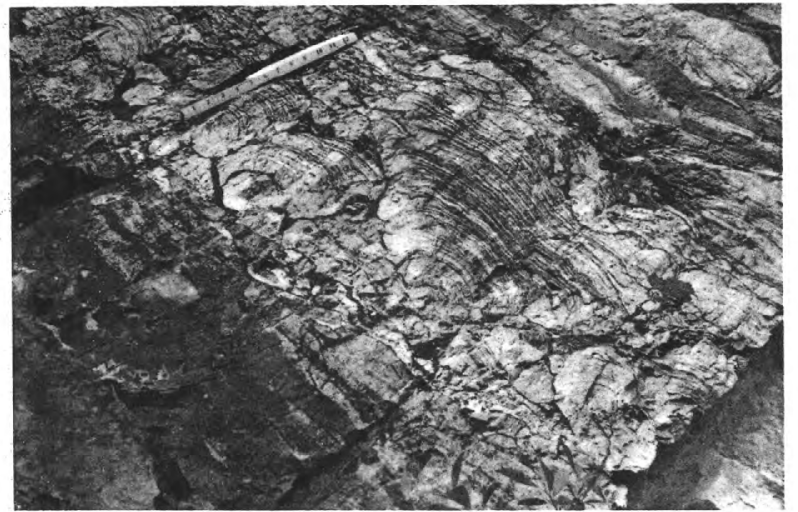

1
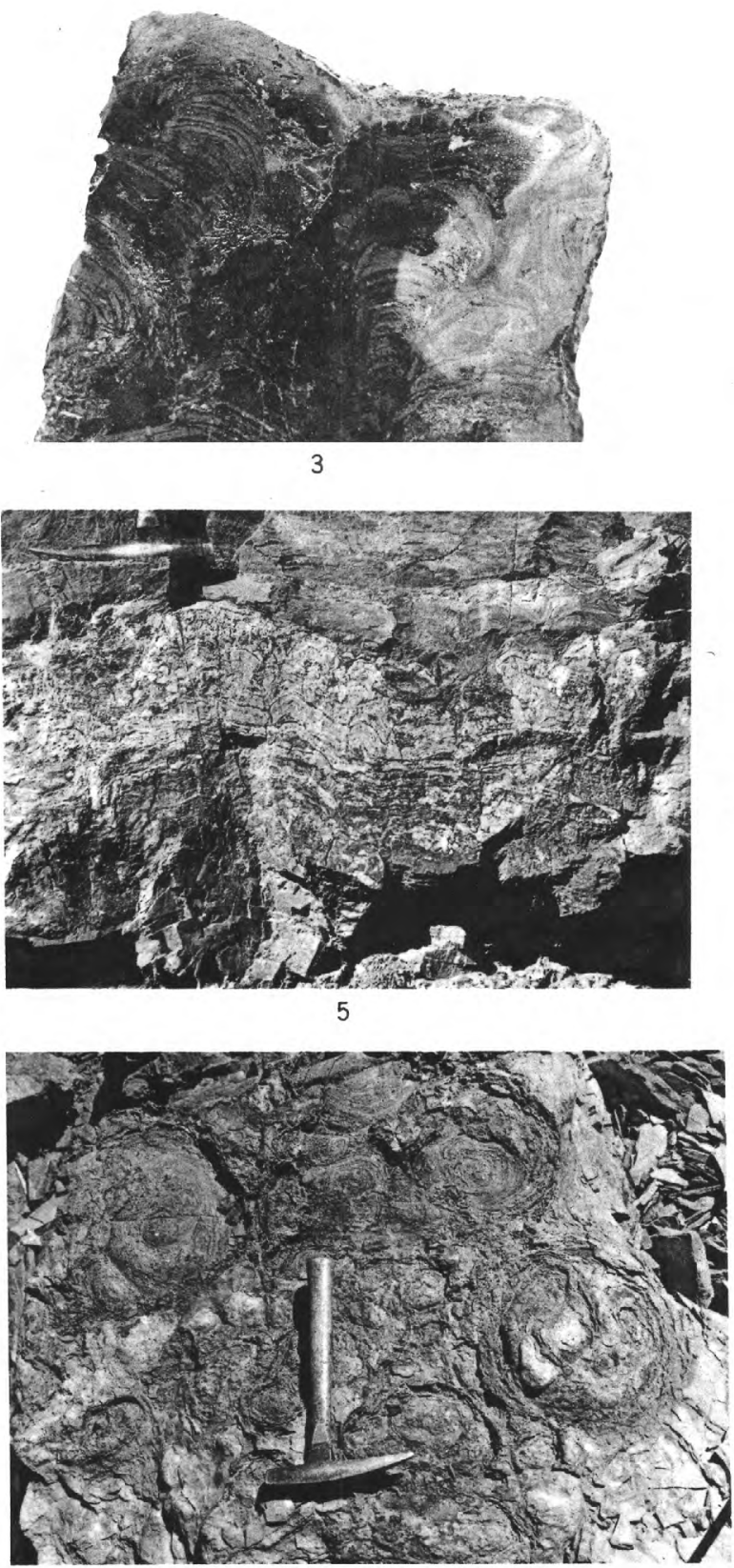
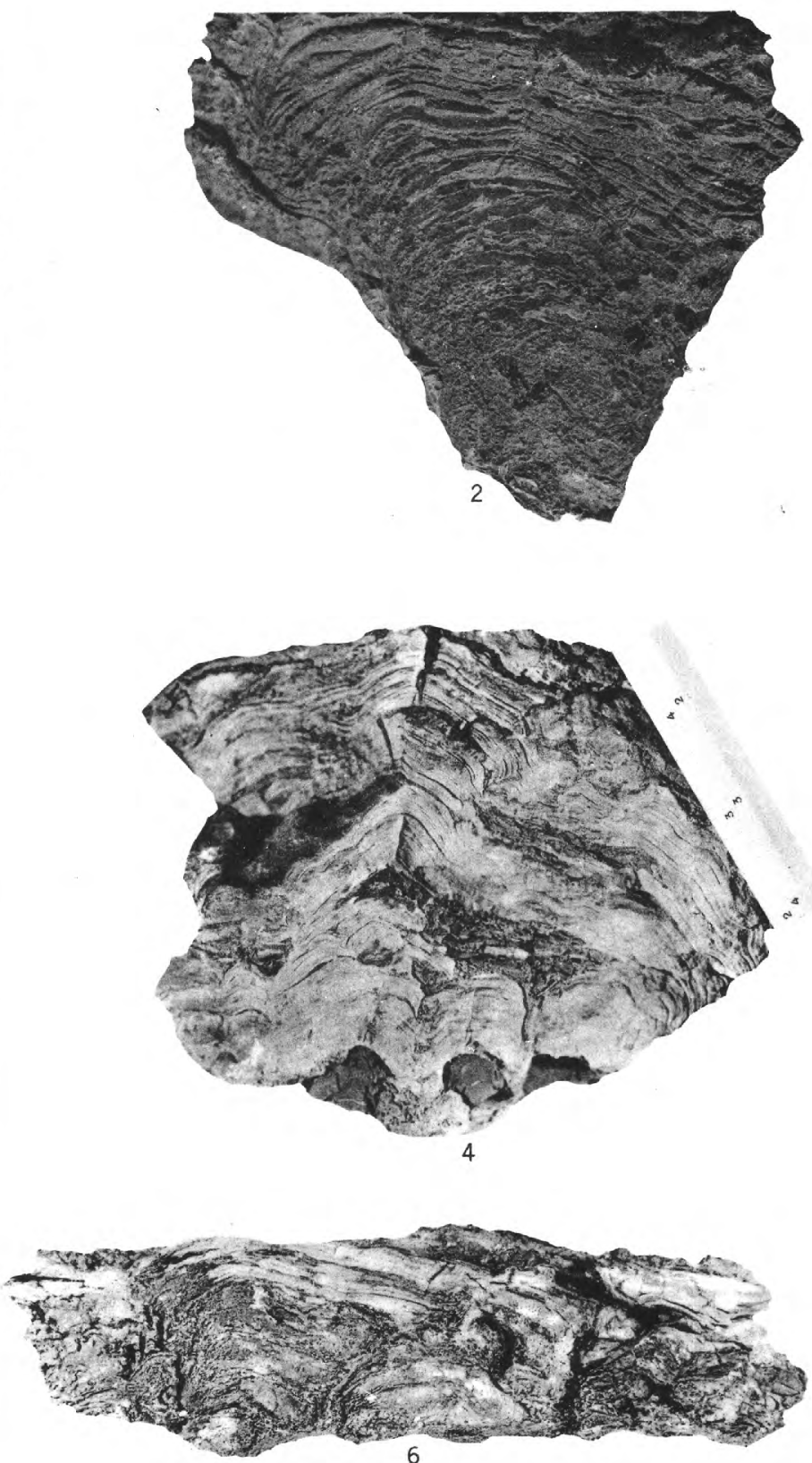

6

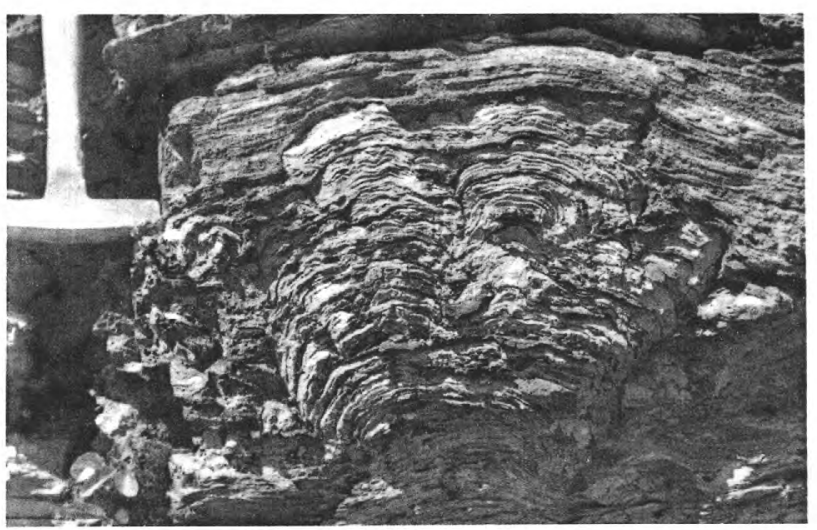




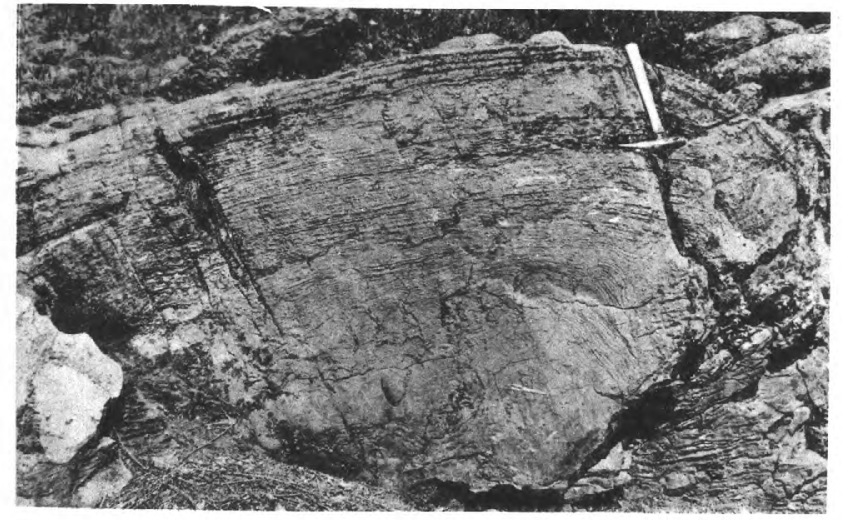

1
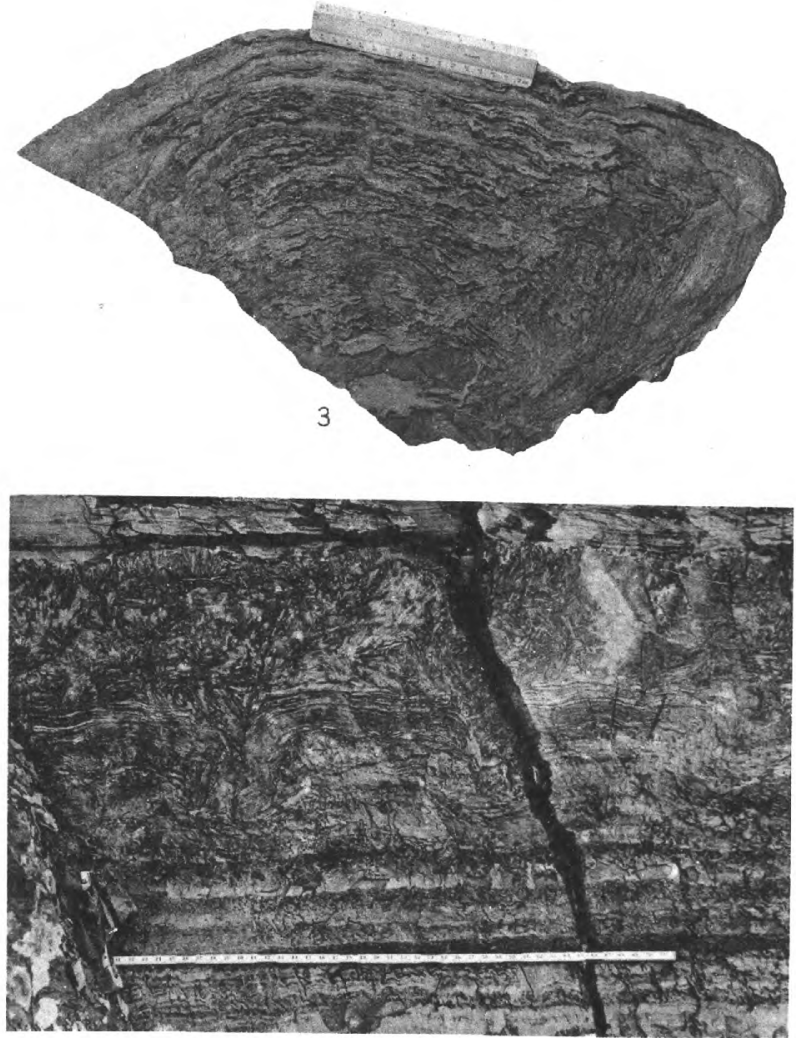

5

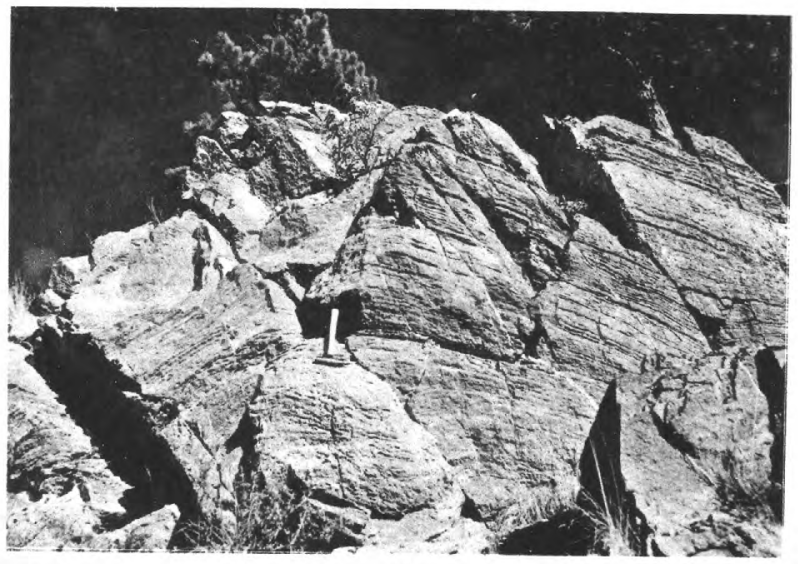

7
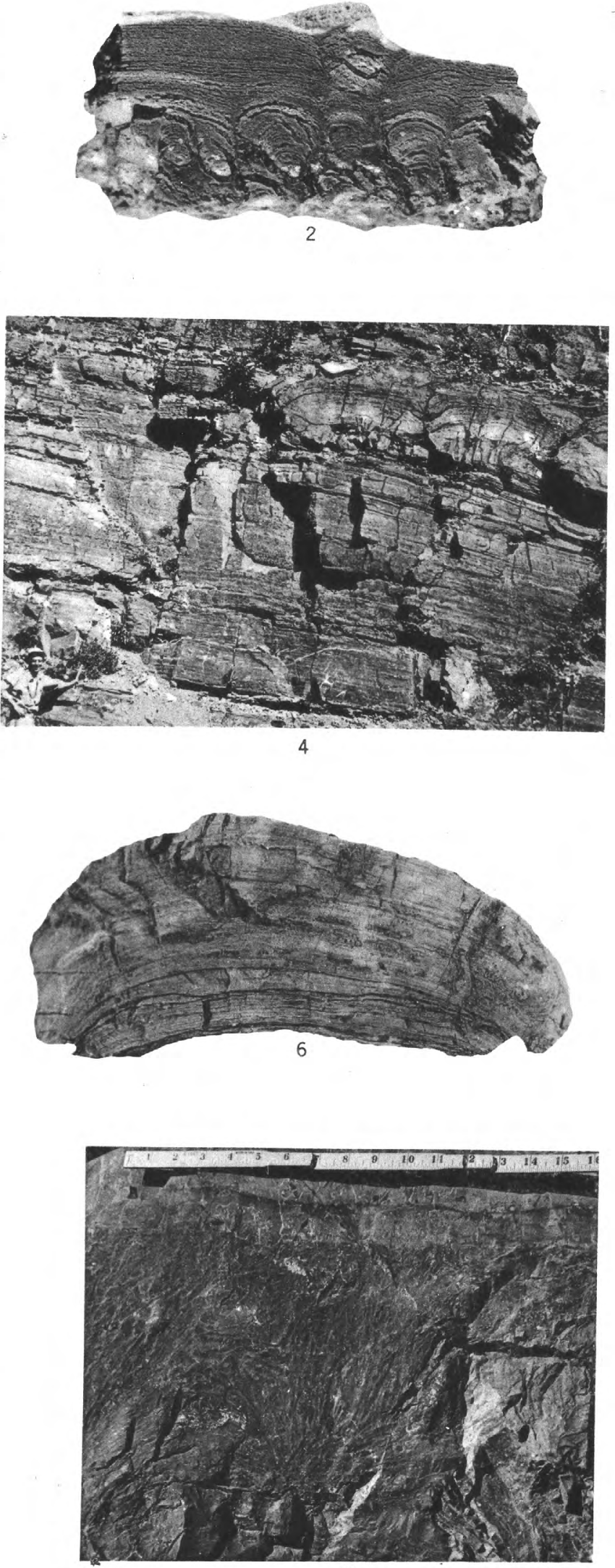


\section{PLATE 22}

Figune 1. Collenia multiflabella n. sp., in Collenia multifiabella zone (p. 134).

Note expanding cylindroids in basal portion of stromatolite that are capped by later continuous laminae. At type site of zone, on east side of Logan Pass just above the point where Reynolds Creek plunges into St. Mary valley.

2. Lithoid tufa (X 1) from Pleistocene shore of Lake Lahonton (p. 145).

Note similarity to Collenia multiflabella n. sp., plate 22, figure 1. USGS a251.

3. Collenia symmetrica Fenton and Fenton, Siyeh limestone (p. 134).

East of West Glacier, Mont., 2.5 miles, on U. S. Highway 2. USGS a1.20.

4. Collenia symmetrica Fenton and Fenton, in Collenia symmetrica zone 2 (p. 134).

Two large colonies in upper right of photograph; note size compared with man at lower left. Just east of snowshed 7 on Great Northern Railway along Bear Creek.

5. Collenia symmetrica Fenton and Fenton, Siyeh limestone (p. 134).

Massive bed above the scale contains $C$. symmetrica overlain by edgewise breccia of stromatolite fragments. At west end of outcrop opposite intersection of North Fork Road and Going-to-the-Sun Highway at south end of Lake McDonald.

6. Collenia symmetrica Fenton and Fenton $(X / 2)(p .134)$.

Holotype of Collenia clappii Fenton and Fenton. PUM 24026.

7. Collenia symmetrica Fenton and Fenton, Helena limestone (p. 134).

Near top of hill 0.7 mile east of western end of Mount Helena Scenic Drive, Helena, Mont.

8. Collenia symmetrica Fenton and Fenton, Siyeh limestone (p. 134).

Colony at left overlain by edgewise breccia. Near observation platform at Hungry Horse Dam, Mont. 


\section{PLATE 23}

Figure 1. Conophyton inclinatum n. sp., in Conophyton zone 2 (p. 135).

Bedding surface does not coincide with axes of cones, which accounts for the rounded nature of the laminae near their apices. Along Great Northern Railway opposite point where Devil Creek flows into Bear Creek.

2. Dendritic tufa $(\times 1 / 4)$ from Pleistocene shore of Lake Lahonton (p. 145). USGS a578.

3. Conophyton inclinatum n. sp., in Conophyton zone 2 (p. 135).

Joint surface shows nearly circular sections normal to axes of cones. Locality same as that for figure 1 of plate 23 .

4. Dendritic tufa $(\times 1 / 4)$, from Pleistocene shore of Lake Lahonton (p. 145).

USGS a.579.

5. Conophyton inclinatum n. sp. ( $\times$ 144), from Conophyton zone 1 (p. 135).

Specimen found weathered out of zone on The Garden Wall trail near Haystack Butte. USGS a119.

6. Conophyton inclinatum n. sp., from Conophyton zone 2 (p. 135).

Holotype. Along Great Northern Railway tracks in Bear Creek valley, opposite mouth of Devil Creek. USGS a2.

7. ?Newlandia sp. ( $\times 1 / 4)$, Prichard formation (p. 134).

Near Pinehurst, Idaho. Resembles Newlandia, however organic origin not certain. USGS al.

8. Newlandia lamellosa Walcott (X 1/4), Newland limestone (p. 134).

Eight miles west of White Sulphur Springs, Mont. Note strongly concave lower surface of stromatolite and very gently coneave laminae. USGA a250.

9. Conophyton inclinatum n. sp., in Conophyton zone 1 (p. 135).

Podlike bioherms with associated finely laminated off-reef deposits common only in this zone. Going-to-the-Sun Highway, 6.4 miles northwest of Logan Pass. 

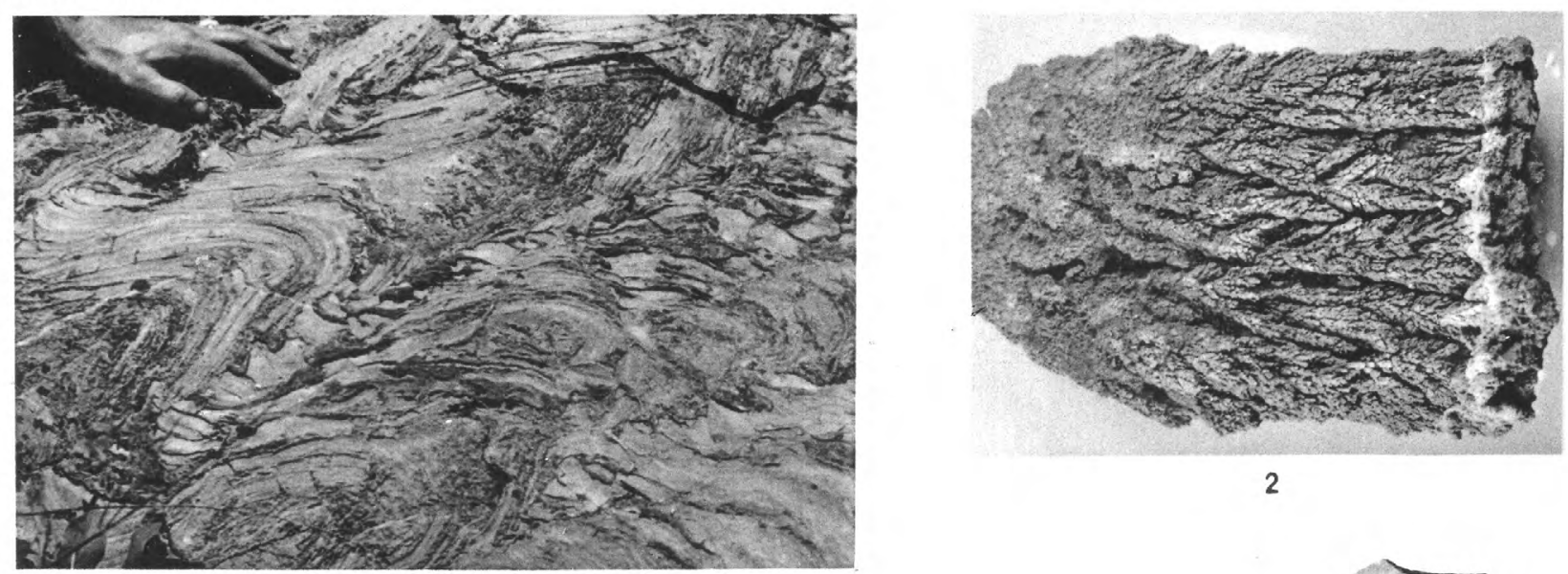

2
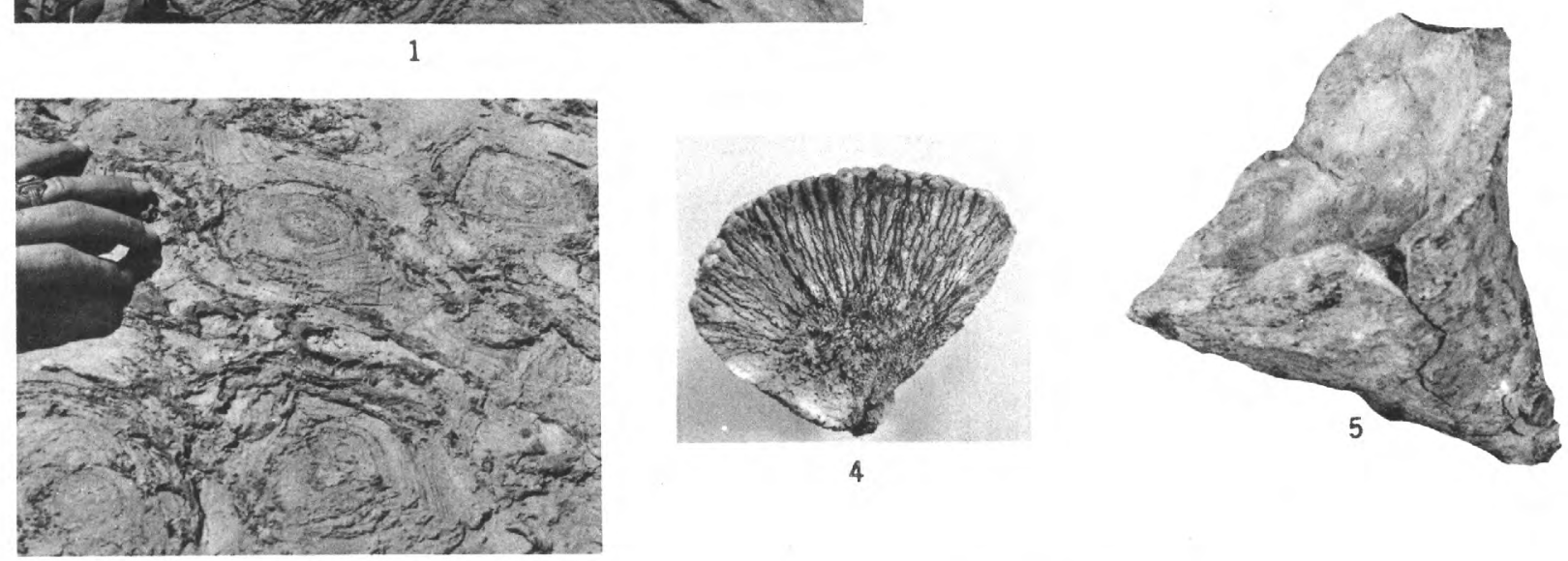

4
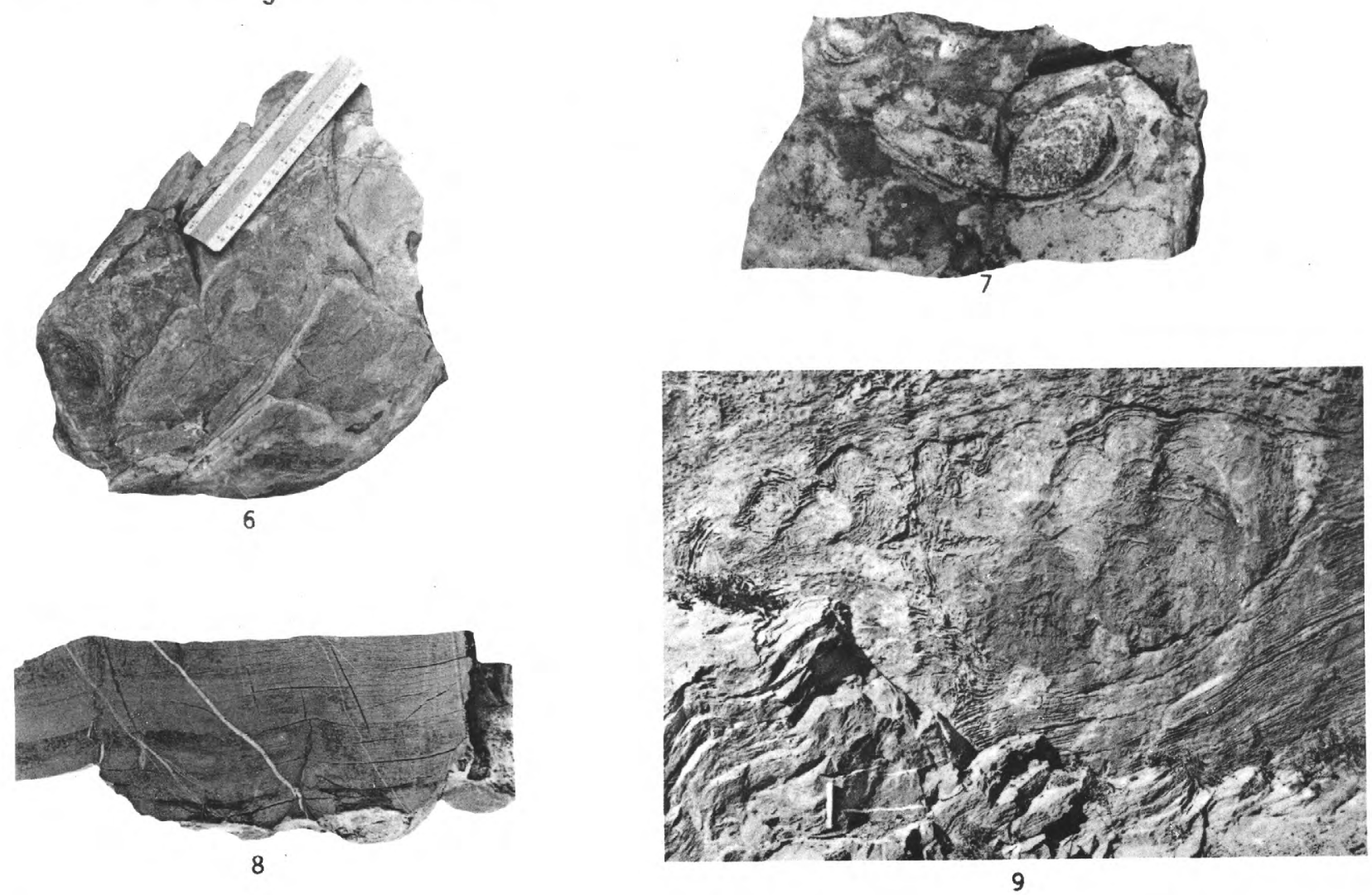

9

CONOPHYTON INCLINATUM, DENDRITIC TUFA, ?NEWLANDIA SP., AND NEWLANDIA LAMELLOSA 

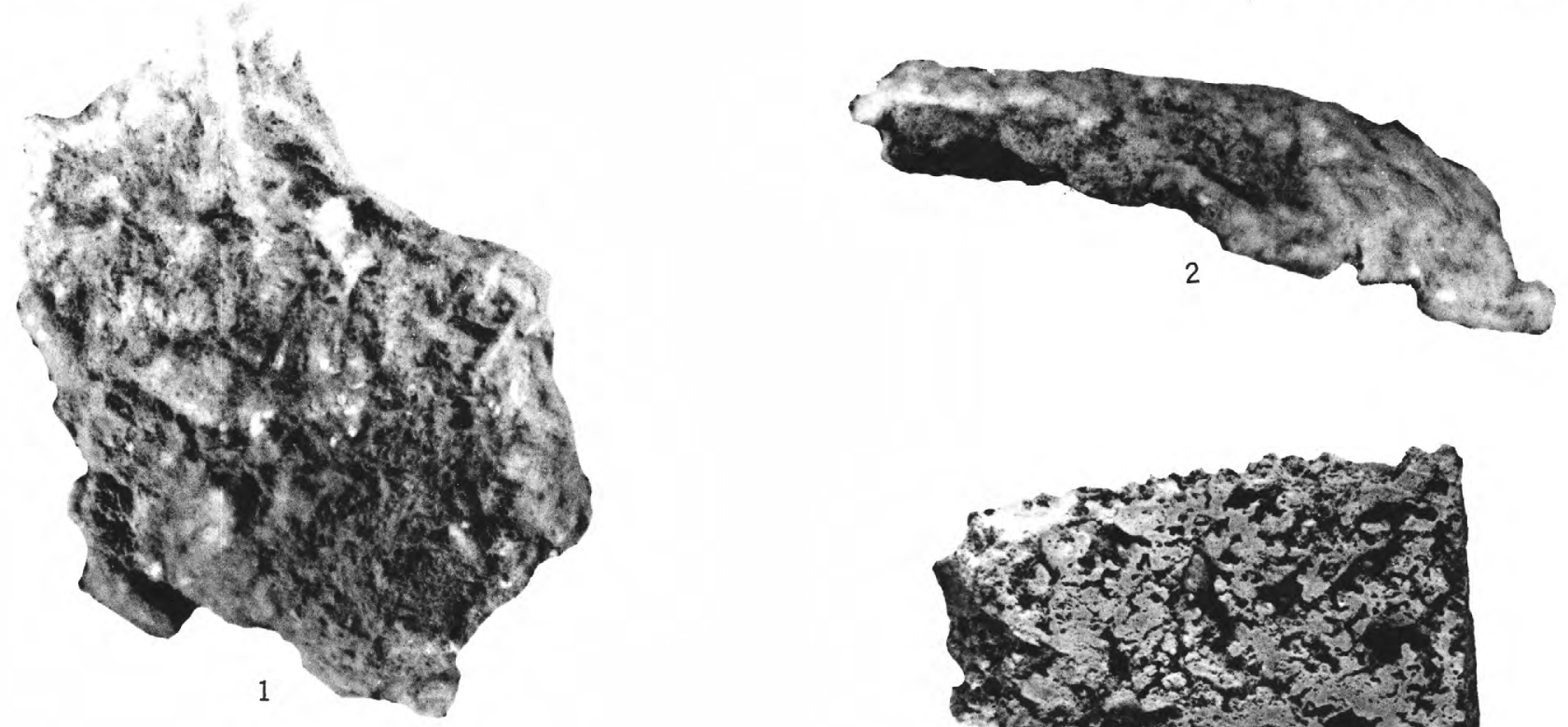

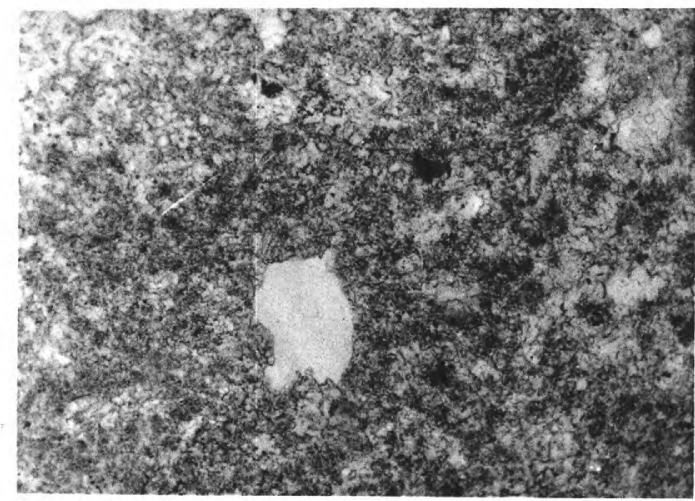

4

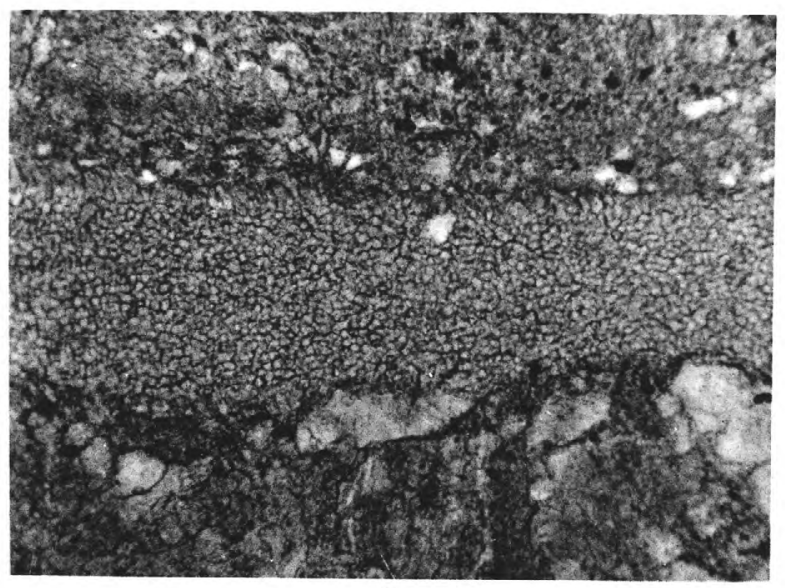

6

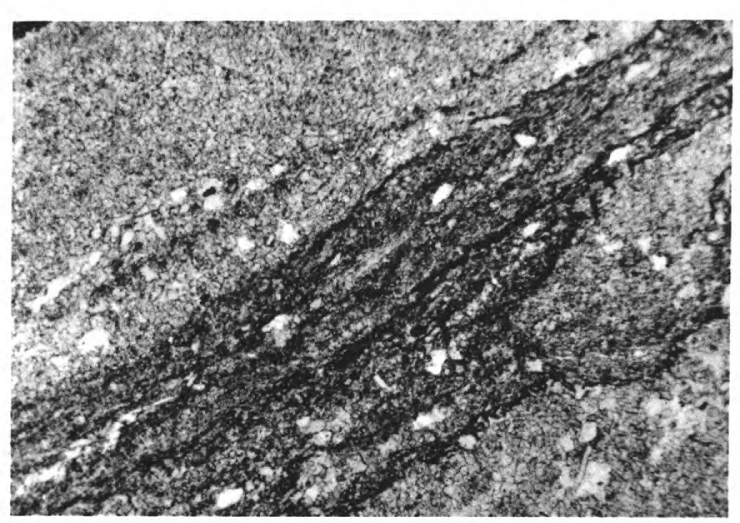

5

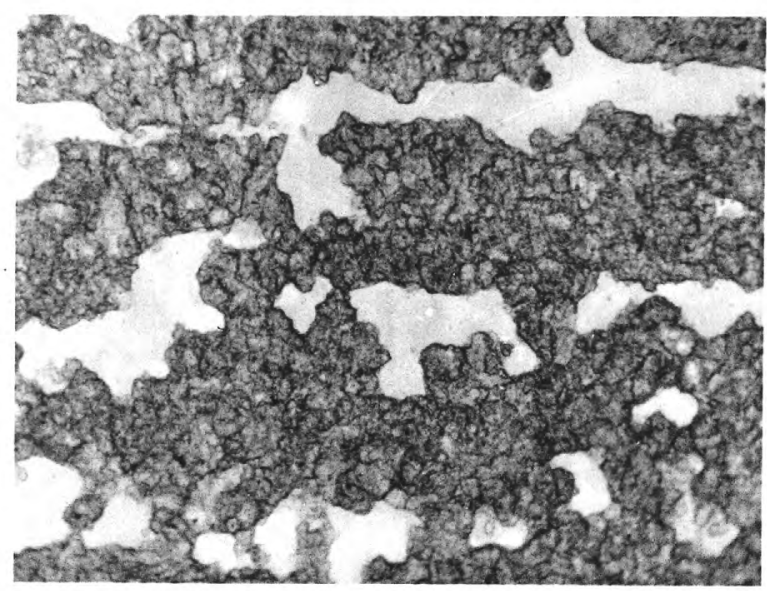

7

RECENT ALGAL DEPOSITS, COLLENIA SP., AND COLLENIA UNDOSA 


\section{PLATE 24}

Figure 1, 2. Recent algal mat ( $\times 1$ ), from shores of Carson Sink, Nev. (p. 145).

Top and side views, showing felt of intertwined algal filaments. Basal part consists of fine-grained sediment bound together by algal filaments. USGS a121.

3. Recent arborescent algal deposit $\left(\times \frac{1}{2}\right.$ ), from Green Lake, N. Y. (p. 144).

Polished section. USGS a252.

4. Recent algal deposit ( $X 50$ ), from Green Lake, N. Y. (pl. 24, fig. 3).

Photomicrograph of slide. Note lack of laminated microstructure. USGS a252a.

5. Collenia sp. ( $\times$ 50) (p. 133).

Photomicrograph showing laminated microstructure. USGS a211a.

6. Collenia undosa Walcott $(\times 50)$ (p. 133).

Photomicrograph showing lamina made up of fine-grained calcite mosaic with coarser grained calcite above and below. USGS a206a.

7. Lithoid tufa from Pleistocene shore of Lake Lahonton ( $X 50)$ (pl. 22, fig. 2).

Photomicrograph of slide. Lighter areas are voids between laminae. USGS a251a. 